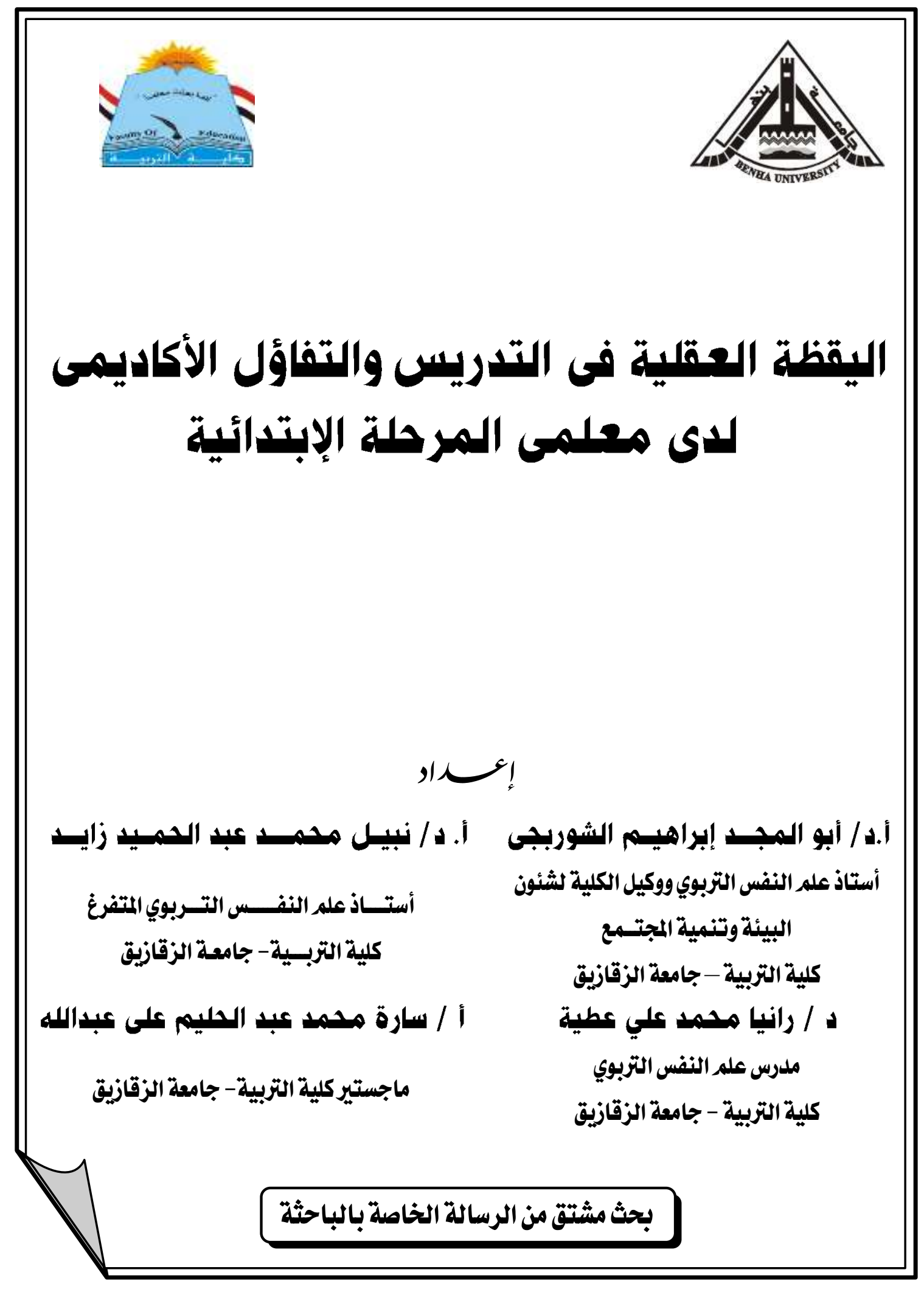


التبؤُ بالأهداف الدافعية للإنجاز لدي لصف الخامس والسادس الابتدائي

من خلال إدراكهم لسلوك معدميهم الفوري اللفظي وغير اللفظي

\section{! !}

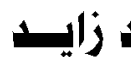

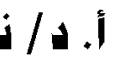

أ.د/ أبو المجـــ إبراهيسم الشوربجى

أستـــاذ علد النفـــس التــربوي المتفرغ

كلية التربـية- جامعة الزقازيق

أستاذ على النفس التربوي ووكيل الكلية لشئون

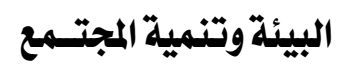

كلية التربية- جامعة الزقازيق

أ / سارة مهمد عبد الدليم على عبدالله

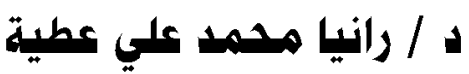

ماجستير كلية التربية- جامعة الزقازيق

ملدرس علد النفس التربوي

كلية التربية - جامعة الزقازيق

هدف البحث الحالي إلى التعرف على الفروق في الأهداف الدافعية للإنجاز وفقا لـتغير

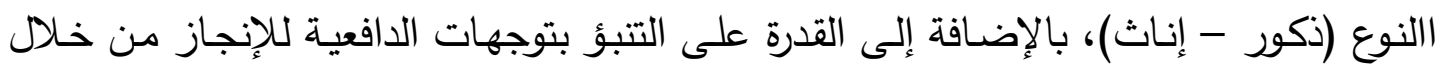

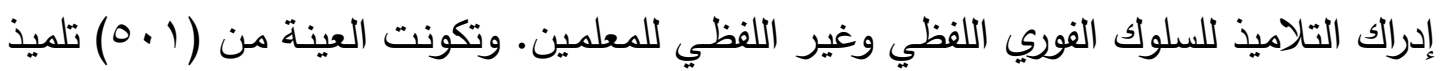

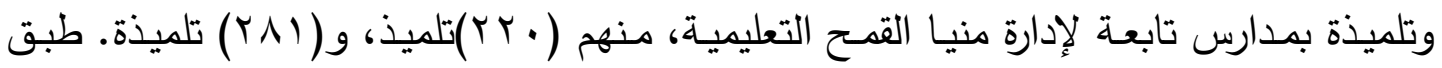

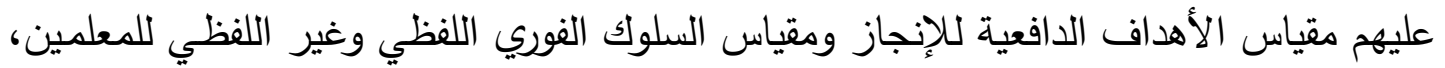

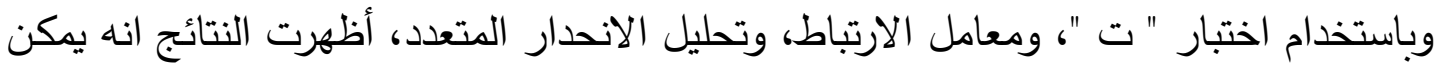

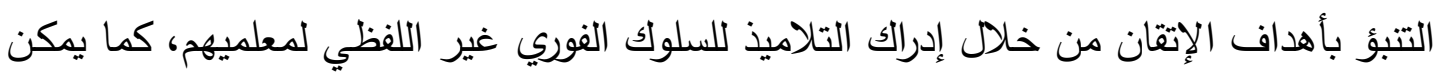

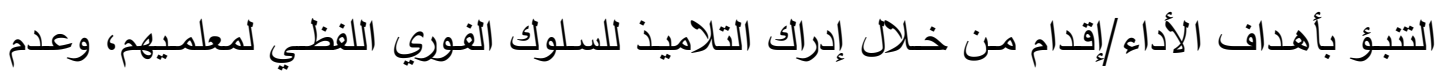

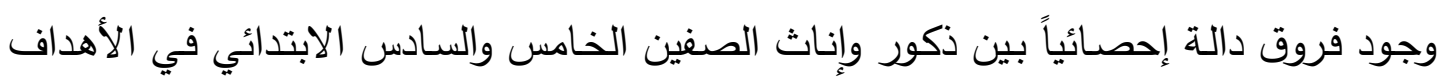
الدافعية للإنجاز (بأبعادها المختلفة). الكلمـات المفتاحية : أهداف الإتقان - أهداف الأداء - السلوك الفوري اللفظي - السلوك الفوري غير اللفظي. 
البمة

يتفق التربويون على أن البيئة التعليمية جزء مهم من العملية التعليمية، حيث ينبغي أن تجذب البيئة التعليميـة المتعلم وتحببـه في التعلم، ومن أجل تلافي أوجـه النقص الأخرى في العملية التعليمية، ولتصبح تلك البيئة التعليمية جاذبة، ينبغي أن تشتمل على التجديد والتتويع في استغلال المعلم لدافعية التلاميذ؛ حتى لا يصيبهم الملل.هذا ويجذب المعلم التلاميذ بسلوكه وتواصـله عـن طريـق خلق جو يسـوده الحـب والمـودة؛ ليسـطيع التلاميذذ إدراك هـذا السـلوك والتفاعل معه للوصول إلى البيئة الجاذبة للمتعلم وإعطائه الدافع للتعلم. وقد يتمثل ذلك أيضا من خلال العوامل الدافعة للمتعلم فيكون لدى المعلم اتجاه الدفء والقبول نحو كل الطلاب، ولا يخاف من إبداء الاهتمام الحقيقي بالطلاب بالربت على أكتافهم، ومساعدتهم بصورة فردية، أو عن طريق المدح الواقعي عندما يعود الطالب لإنجازه الطبيعي بعد أن لاحظت عليه أنه يبذل مجهوداً أقل كثيرا من المعتاد، وإعطاء الثناء على الإنجازات (نبيل

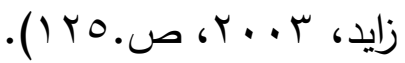

ويرى "ديسى ورايان، " • 99 (" “Deci\&Rayn, 1990” أن إثارة الدافعية لدى الطلاب تجعل عملية تعلمهم أكثر فاعلية، وعملية تفاعلهم المدرسي والصفي أكثر إيجابيـة وتزيد من حماسـهم للإثـرالك في مواقف التعلم الصفية، والدافعيـة للتعلم الصـفي لها أهميـة في زيـادة انتبـاه الطالب، وزيادة وقت اندماجـه في الأنشطة التعليمية وتركيز عزوه في نجاحه وفثـله إلى عوامل داخلية، وسيطرته على العوامل المؤثرة في إنجاز مهمة التّعلم، ويسهم ذلك في زيادة جهده وسيطرته

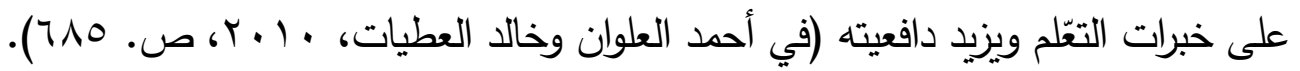

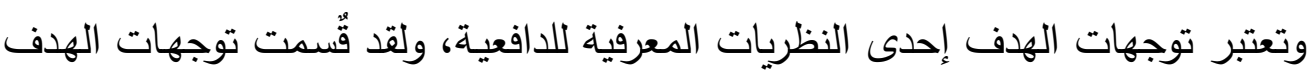
في بداية الأمر إلى أهداف الإتقان أو التعلم، وأهداف الأداء، وتركز أهداف الإتقان على المدى الذي يؤكد فيه الفرد على إجادة التعلم والتطور أثناء تقدمه في المهام، بينما تصف أهداف الأداء الـــي يقتـرب إليـــه الفـرد مــن المهــام مــع التركيـز علــى الأداء بالنســبة للآخــرين. (Radovseich, D.J, Allyn, M.R\&Yun,S, 2007, P. 26) Mustafa, S. M, Roslan, H. E\& Noah, S .M, وقد كثفت نتائج بحث 2011) أن أهداف الإتقان والأداء لها تأثير كبير على عملية التعليم ومن خلالهما يمكن التنبؤ بقدرة الطالب على الاندماج في التعلم، كما كشفت دراسة (Broussard, 2002) أن لدافعيـة أهداف الإتقان دور كبير في التحصيل الدراسي، أمسا بحث(Smart, 2009) فتوصل إلى أن 
التفاعلات بين المعلم والطالب لها تأثير ايجابي على نتائج انجاز الطالب، فالمعلم الذي يمتلك خصائص تمكنه من التفاعل ايجابيا مع الطلاب يؤثر ايجابيا في نتائج تعلم هؤلاء الطلاب، لهابل وهذه الخصائص من وجهة نظر (Gardiner\& Kozmitzki, 2008) هي التفاعلات الثابتة والمحترمة وعندما يدركها الطالب يكون أكثر اندماجا في عملية التعلم وتدفعه لطلب المساعدة، الذي بدوره يرتبط بثكل ايجابي مع التحصيل الدراسي. وكثفت نتائج بحث (السيد عبدالمعطى، 997 (1) ) عن وجود علاقة موجبة بين الدافع لئح لللراسة والبيئة التي يهيئها المعلم للتلاميذ من جو انفعالي عقلي يتسم بالحب والعطف ويقوم

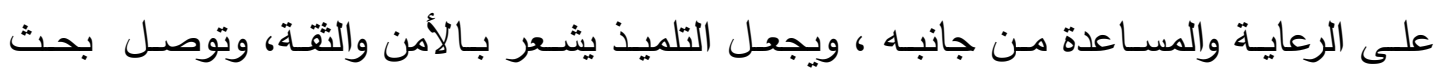

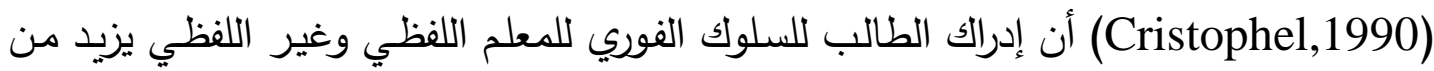

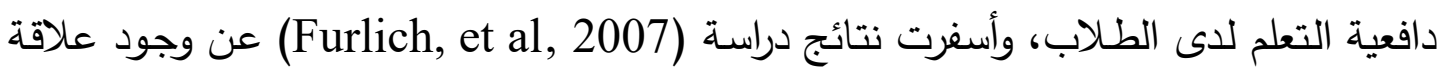

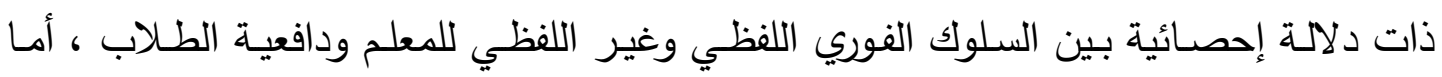
بحث (2010, Tum) فبين أن بعض السلوكيات التي يمارسها المعلم مثل الابتسام والاتصال

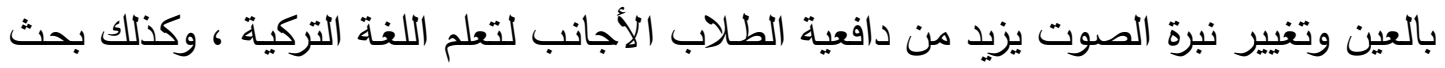
(Johan, 2012)

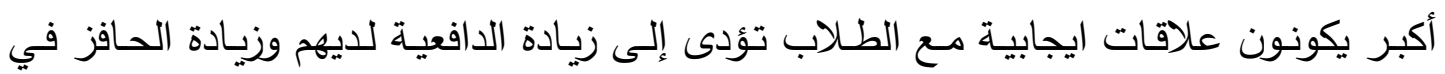
التحصيل الدراسي.

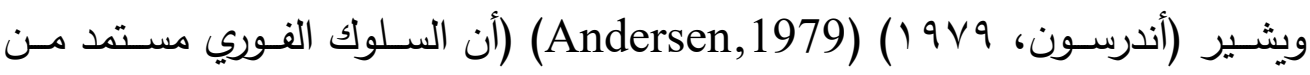

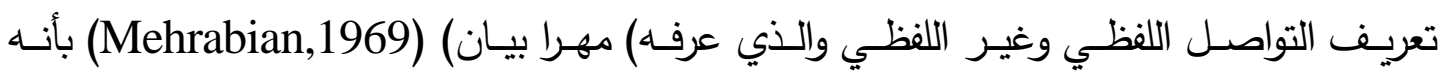

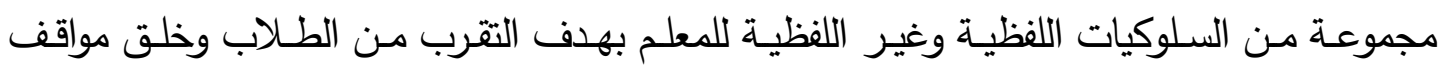
ايجابية من خلال خفض المسافة النفسية والجسدية بين المعلم والطلاب، فالمعلمون الذين يبدون

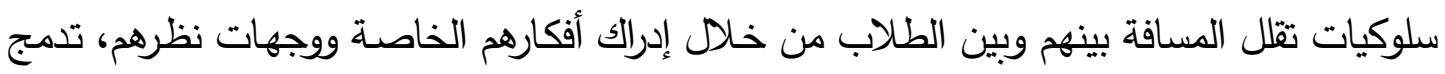
الطالب في البيئة التعليمية، وتتيح للطالب الانخراط وتعظيم التعليم (In: Lane, 2009, p. 2). وقد عُرف التواصل اللفظي بأنه هذا النوع من الاتصـال الذي يقوم فيها المعلم فيه بإرسال

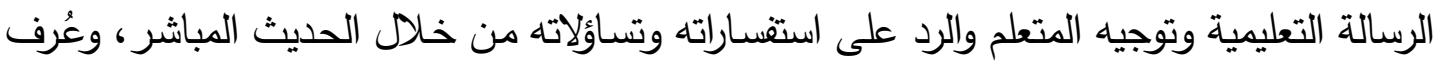

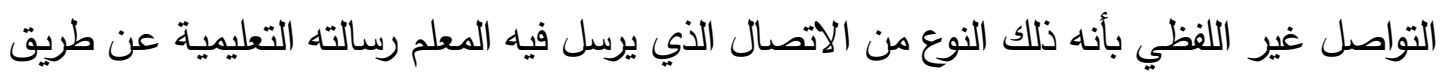

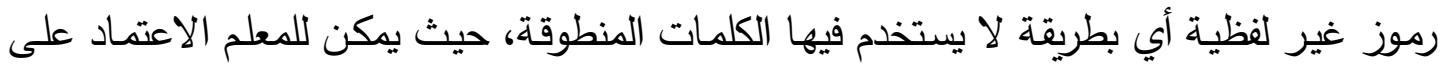


الكلمـات المكتوبـة والرسـوم واللوحـات والصـور والرمـوز البصـرية عمومـا، والإثـارات والإيمـاءات ونظرات العين إلى غير ذلك ( حسن شحاتة وزينب النجار، r . . rكص. (r).

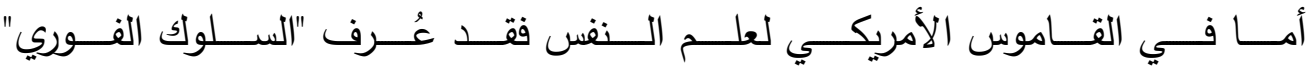
الاتهال بالنها نشاط حركي أو جسمي بين شخصين أو أكثر من خلال

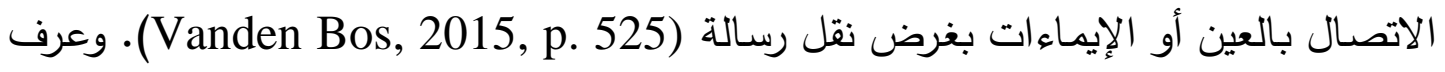

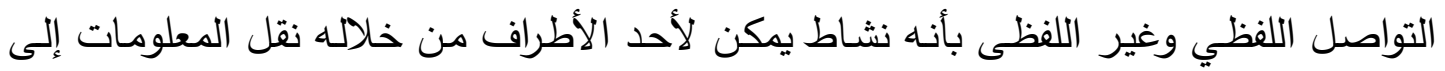

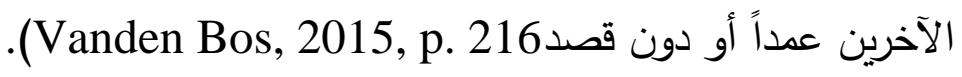
وذلك يؤكد استمداد تعريف السلوك الفوري من التواصل اللفظي وغير اللفظي، ويمكن اعتبار السلوك الفوري هو فنيات التواصل اللفظي وغير اللفظي. وتري (ريتشموند وآخرون، 9AV (1) أن التعليم والتواصل اللفظي وغير اللفظي مجاتلان

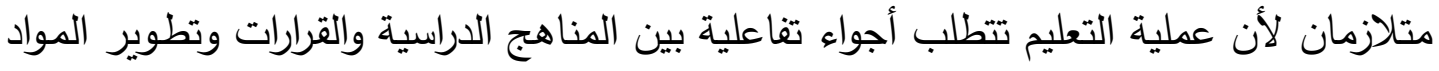

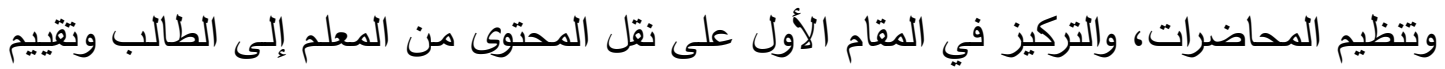
فهم الطلاب وبقاء هذا المحتوى. (In: Aydin et al,2013,p. 28)

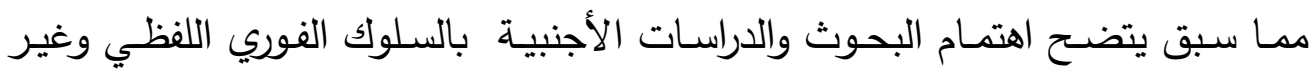

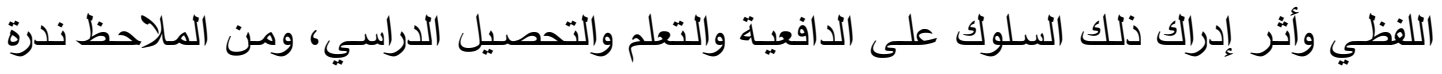
البحوث العربية التي تتاولت متغيرات البحث الحالي في البيئة العربية على الرغم من أهمية تلك الكئك

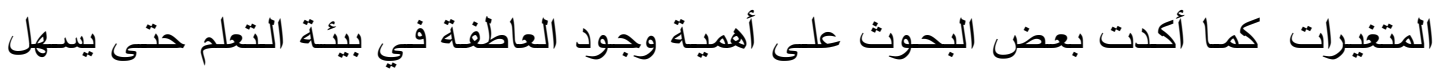
التعامل بين المعلم والتلاميذ وتحسين مستوى التحصيل الدراسي والتعلم المعرفي والوجداني

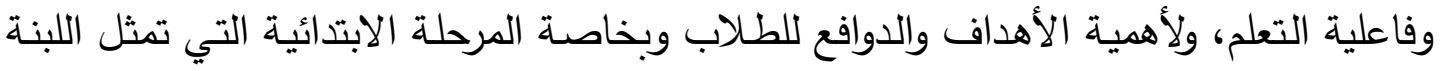

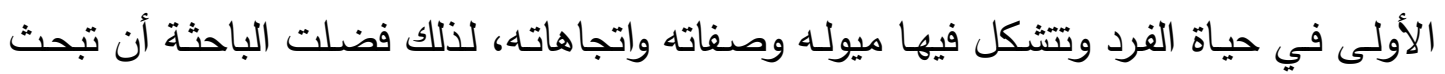
علاقة السلوك الفوري بأهداف الإتقان والأداء لاى تلاميذ المرحلة الابتدائية وبالتحديد الصفين

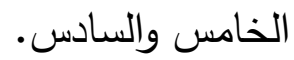

\section{مشكاسلة البحـث:}

وعلى ذلك يمكن تحديد مشكلة هذا البحث في الأسئلة التالية:

1- هل يمكن التتبؤ بأهداف الإتقان لتلاميذ الصفين الخامس والسادس الابتدائي من خلال إدراكهم للسلوك الفوري اللفظي وغير اللفظي لمعلميهج? 
r- هل يمكن التتبؤ بأهداف الأداء لتلاميذ الصفين الخامس والسادس الابتدائي من خلال

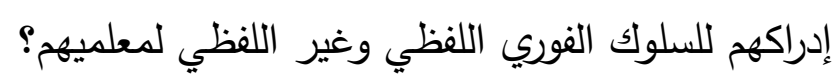

r- هل توجد فروق بين البنين والبنات من تلاميذ الصفين الخامس والسادس الابتدائي في

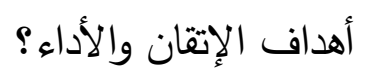

$$
\text { يهذف البحث الحالي إلى التعرف على: }
$$

1- إمكانية التنبؤ بأهداف الإتقان للتلاميذ من خلال إدراكهم لسلوك معلميهم الفوري اللفظي

$$
\text { وغير اللفظي. }
$$

ץ- إمكانية التنبؤ بأهداف والأداء للتلاميذ من خلال إدراكهم لسلوك معلميهم الفوري اللفظي

$$
\text { وغير اللفظي }
$$

r- دراسـة الفروق بين الجنسين في أهداف الإتقان والأداء لدي تلاميذ الصفين الخـامس

$$
\text { والسادس الابتدائي. }
$$

\section{تتحدد أهمية البحث الحالي في النقاط الآتية:}

1- دراسة الفروق بين الجنسين في الأهداف الدافعية للإنجاز (بأبعادها المختلفة).

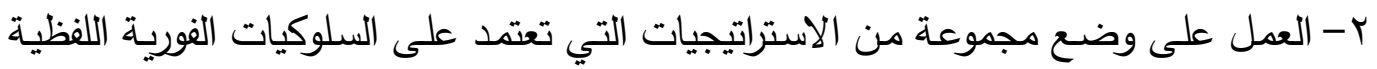
وغير اللفظية لتمكن المعلمين من أداء يساعد على تحقيق الدافعية للتعلم للى تلاميذهم.

• أهداف الإتقان/ إقدام: Mastery-Approach Goals هي تلك الأهداف التي تركز على الإتقان والتعلم والفهم وتطوير الكفاءة.

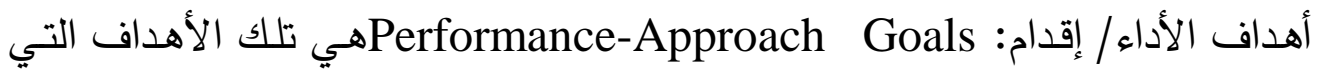
تركز على التفوق على الآخرين وإظهار القدرة، وتحسن الأداء مقارنة بالآخرين.

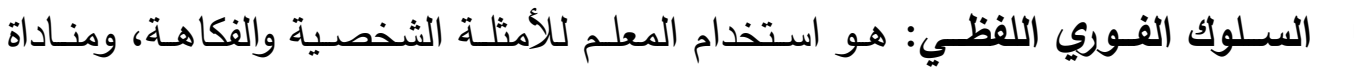

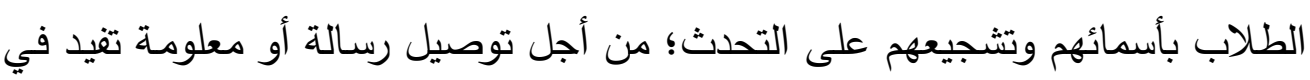
تعظيم التعلم المعرفي (Gorham, 1988, p. 40). 
" السلوك الفوري غير اللفظي: هو كل مـا يصدر عن المعلم من حركات كالإشـارة

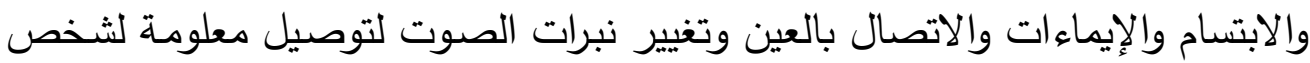

أو أكثر (Gorham, 1988, p. 40).

\section{تثمل حدود البحث ما يأتي:}

حد بشري: تلاميذ الصفين الخامس والسادس من المرحلة الابتدائية (ذكور - إناث).

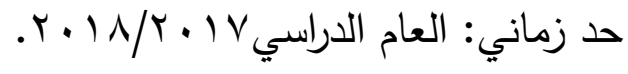

حد مكاني: مدارس التعليم الابتدائي بإدارة منيا القمح التعليمية بمحافظة الثرقية. حد موضوعي: الأهداف الدافعية للإنجاز - السلوك معلميهم الفوري اللفظي وغير اللفظي.

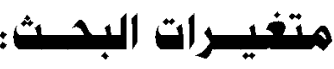

\section{أولا : الــلـافيـــــة}

يلعب مفهوم الدافعية دور العصب في الحياة النفية وعلم النفس فيرى (بيرد) (Bird)

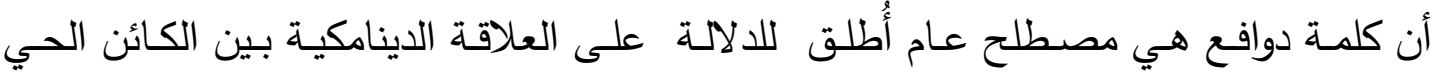
وبيئته، وأن اللفظ لا يعنى ظاهرة سلوكية يمكن ملاحظتها، وإنما يعنى فكرة تكونت بطريقة الاستدلال ولابد من التسليم بوجودها لأن الأفراد لا يستجييون للموقف بطريقة واحدة، ومن ثنان

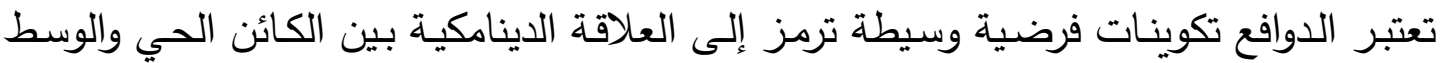

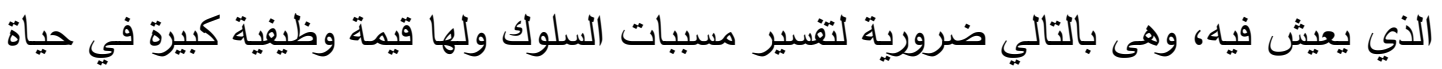

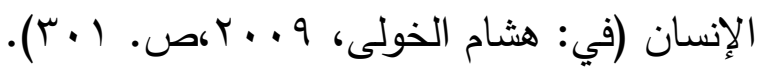

وكثيرا ما يتساءل الآباء والمعلمون عن أسباب اختلاف الطلاب في رجاعهم نحو نشاط أو مـادة دراسية، فالبعض يقبل على النشاطات المدرسية بحماس كبير جدا، فحين يرفضـها

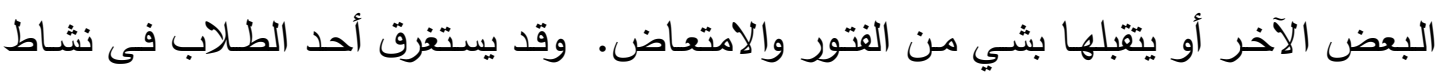
دراسي ساعات طويلة، بينما لا يستطيع طالب آخر أن يثابر علي هذا النشاط فترة قصيرة جدا، ويسعى بعض الطلاب إلى الحصول على مستويات تحصيلية متفوقة في الوقت الذي يرضى

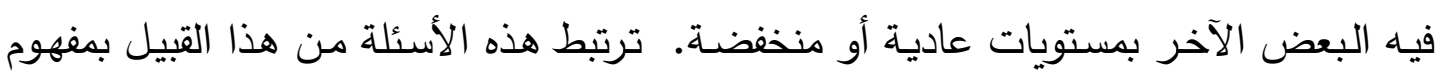
الدافعية الذي يعتبره الباحثون فى التربية وعلم النفس أحد العوامل المسئولة عن اختلاف الطلاب التاب

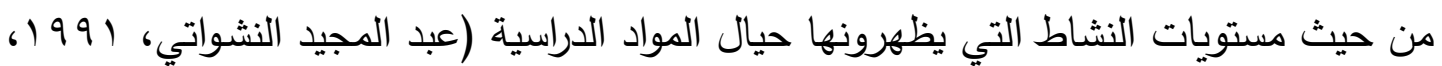

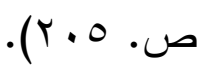




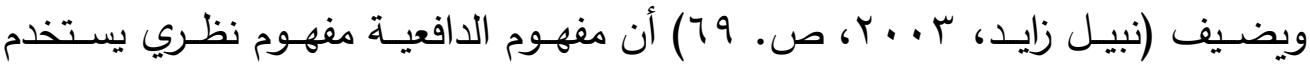
لتقسير المبادرة والاتجاه والثدة والمثابرة في السلوك، وخاصة السلوك الموجه نحو هدف. وفى نطاق حجرة الدراسـة يستخدم مفهوم دافعية الطالب لتفسير الدرجة التي يقوم عندها الطـلاب باستثمار انتباههم ومجهودهم في مختلف الاتجاهات التي قد تكون مرغوبة من قبل المدرسين.

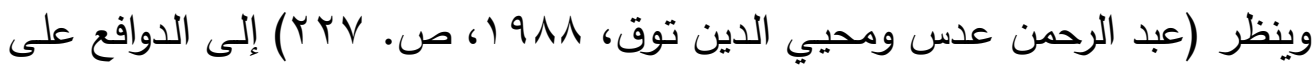

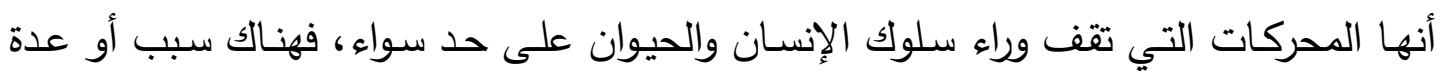
أسباب وراء كل سلوك، وهذه الأسباب ترتبط بحالة الكائن الحى الداخلية وقت حدوث السلوك

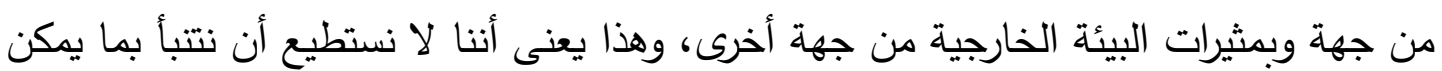

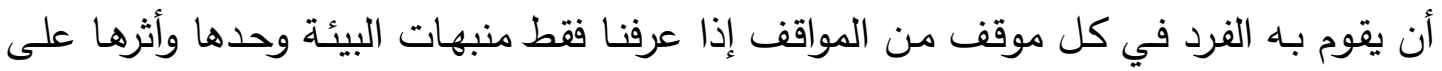

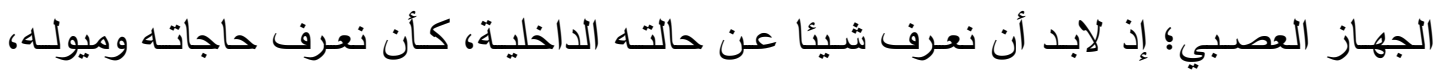

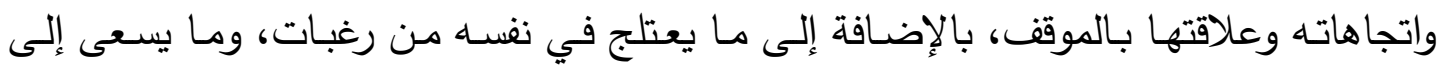
تحقيقه من أهداف. هذه العوامل مجتمعه هي ما نسميه بالدوافح.

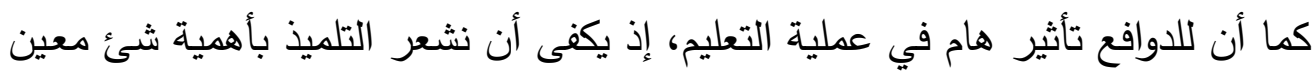

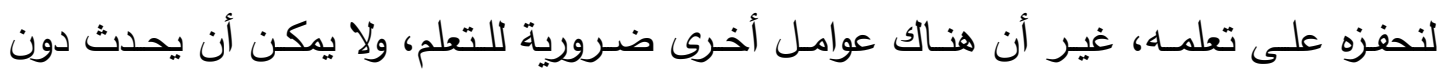

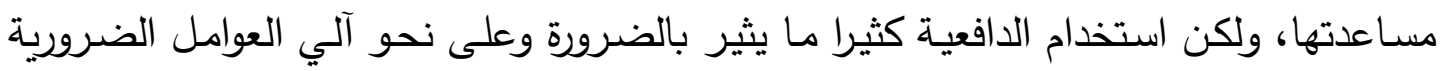

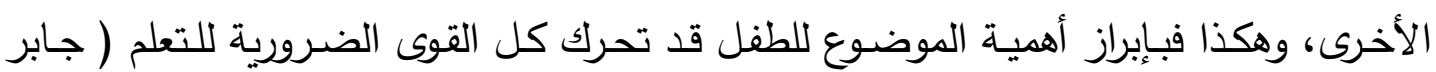

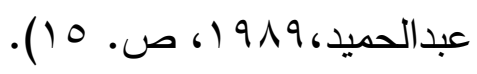

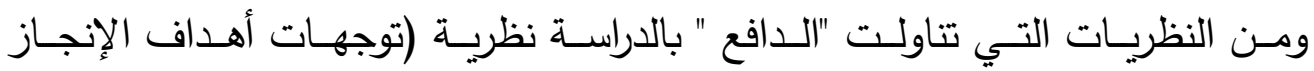

التي ظهرت كاتجاه جديد في أبحاث الدافعية في الإطار الاجتماعي - المعرفي والتي تركز على الهدف أو السبب أو الغرض الذي ينشده الفرد

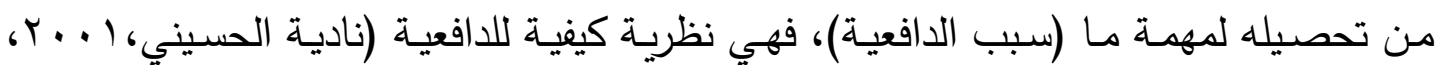

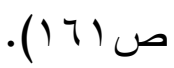

\section{Theory Achievement Goal نظرية توجمات أهداف الإنجاز} تعد نظرية توجهات أهداف الإنجاز من أحدث النظريات المعرفية في الدافعية، وتقوم

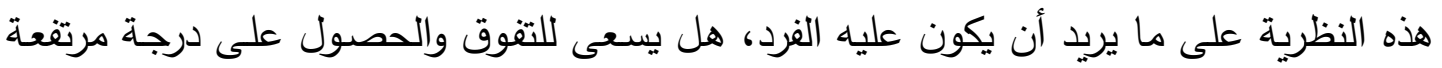

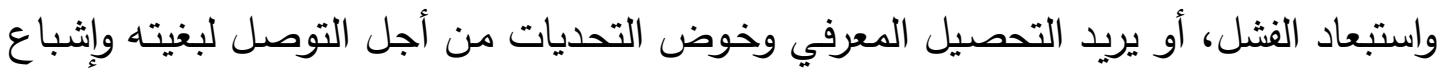


رغبته في المعرفة والتمتع بتلك العمليات، فالنوع الأول يتبنى أهداف الأداء وما يهمه هو نظرة

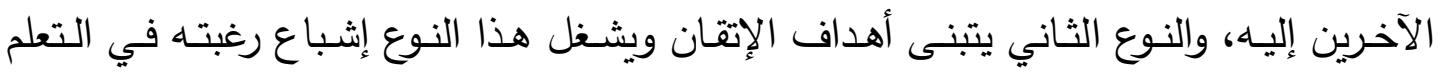

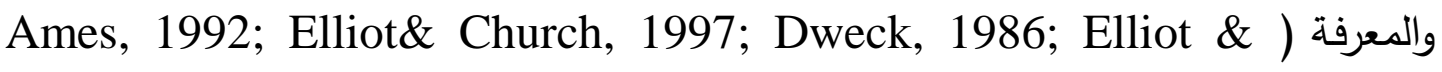

.(McGregor, 2001; Pintrich, 2000

وأضافت (Ames, 1992, Dweck, 1986) أن توجهات أهداف الأداء تشير إلى )

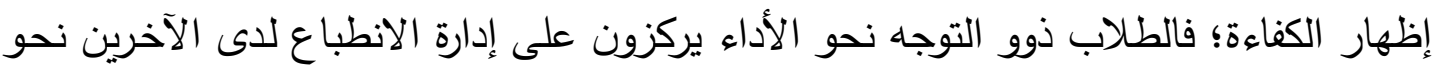

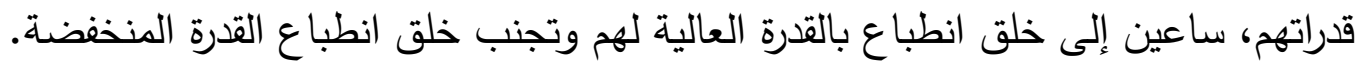

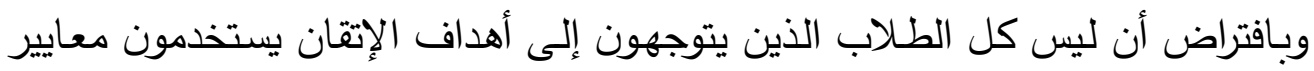
متطابقة لبلوغ الإتقان والإجادة، فقد ميز (Niemivirta, 2002) بين توجهات أهداف الإتقان

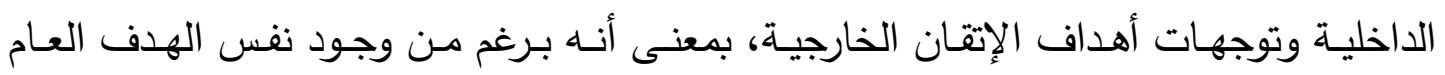

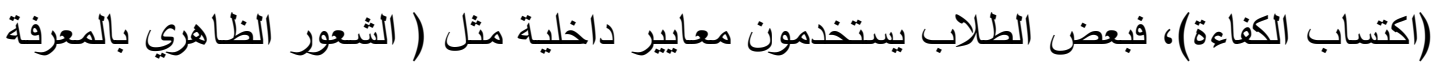

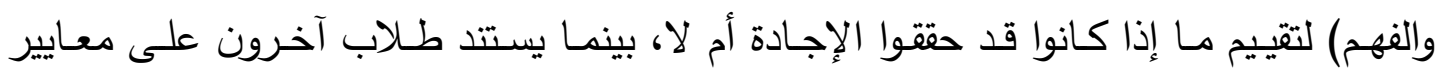

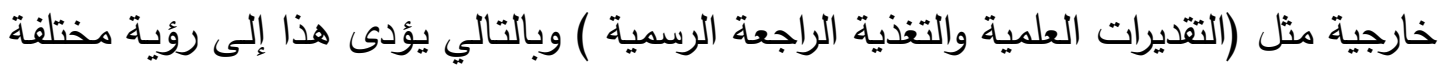
لما يسعى الطلاب لبلوغه . (In: Soini, Aro, \&Niemivirta, 2008, p. 252) ويشير (Pintrich, 2000, p. 12) أن توجهات الأهداف ما هي إلا تمثيلات معرفية

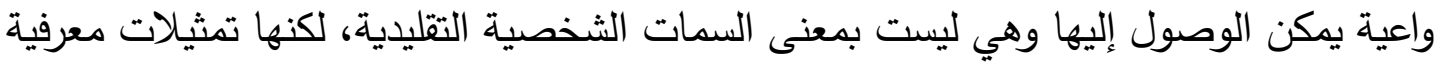

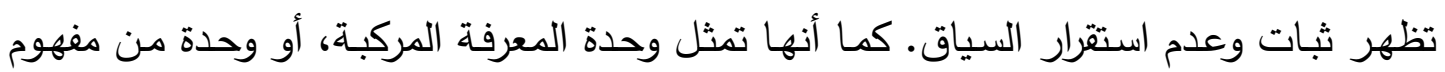

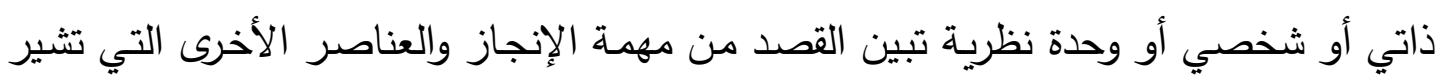

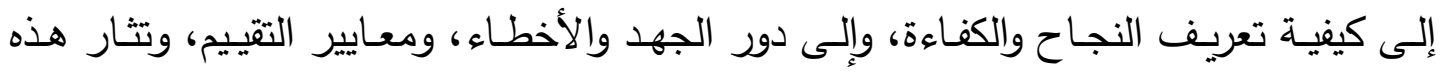

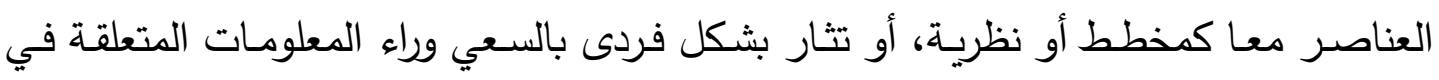
الموضوع أو بواسطة التنكير الظاهري الواعي، أو المعرفة بمهمة الإنجاز .

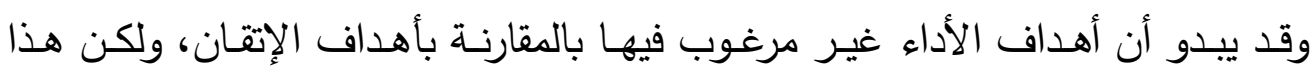

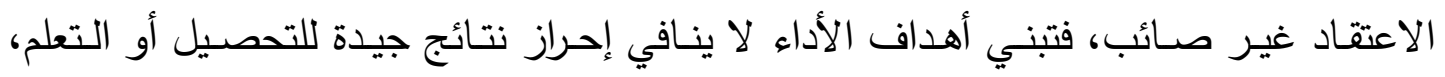

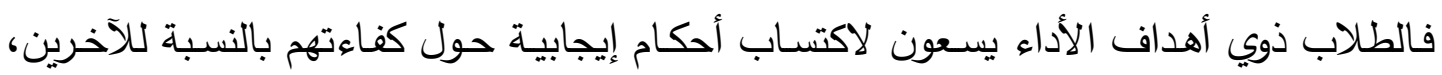
بينما أصحاب أهداف الإتقان يسعون لتجنب الأحكام السلبية على كفاءتهم بالمقارنة بالآخرين،

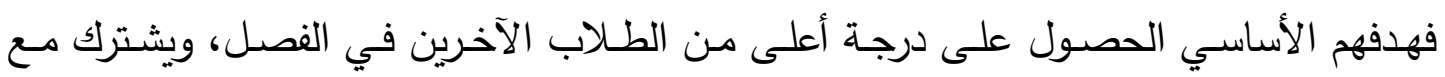
أصحاب أهداف الأداء (Mustafa, et al, 2011, Pintrich, 2000). 
ونظرية توجه الهدف أو توجهات أهداف الإنجاز تفسر دافعية الطلاب بالنظر الي سلوكهم، والفروق التي تظهر في سلوكياتهم. وتعرف هدف الإتقان من خلال تلك النظرية بأنها أهداف الفرد نحو تطوير الكفاءة حيث يركز الفرد على التعلم والفهم وتطوير المهارات وإتقان المعلومات، وتعرف فئات

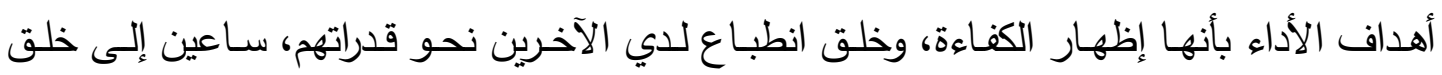
انطباع بالقدرة العالية وتجنب خلق انطباع بالقدرة المنخفضة لديهم. (Ames, 1992, p. 262).

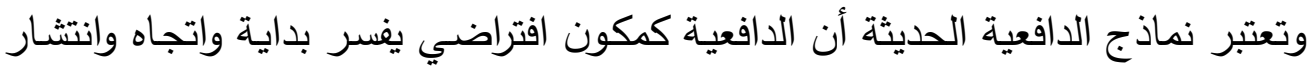

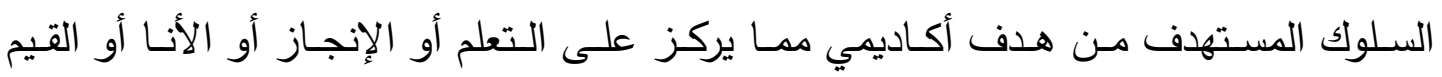

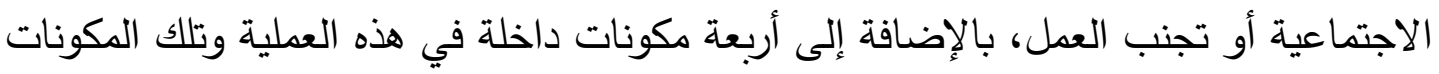

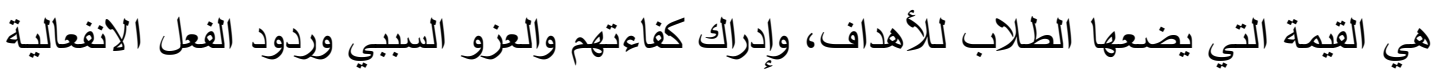
(Arias, 2002, p. 36)

مما سبق يتبين أن نظرية توجه الهدف أو توجهات أهداف الإنجاز تقسر اختلاف دور

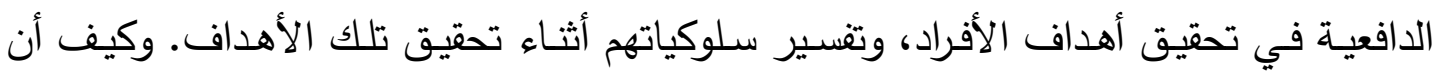

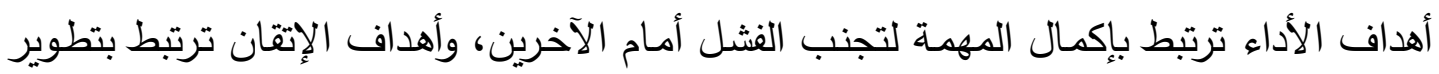

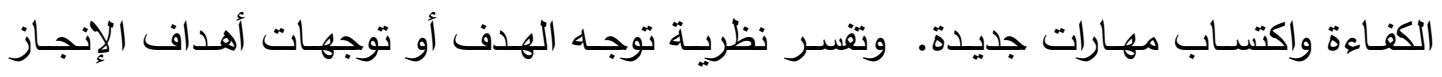
اختلاف دور الدافعية في تحقيق أهداف الأفراد، وتفسير سلوكياتهم أثناء تحقيق تلك الكات الأهداف.

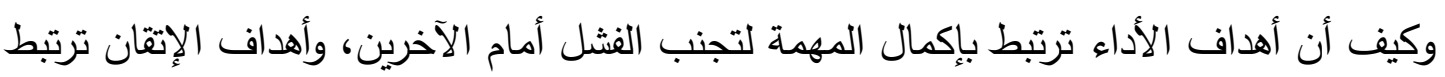

بتطوير الكفاءة واكتساب مهارات جديدة (Somuncuoglu\& Yildirm, 1999, p. 267). من خلال أدبيات البحث يتضح أن نظرية توجهات أهداف الإنجاز تفسر الدافعية من خلاد

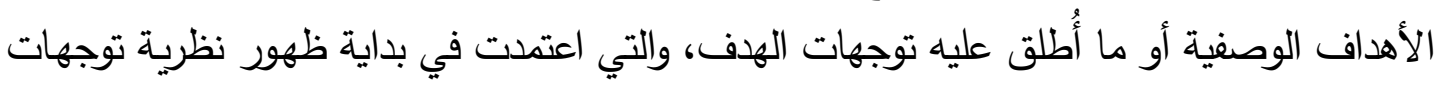
أهداف الإنجاز علي أهداف الإتقان وأهداف الأداء، وتطورت النظرية ليدمج مكوني الإلفات الإقدام والتجنب:

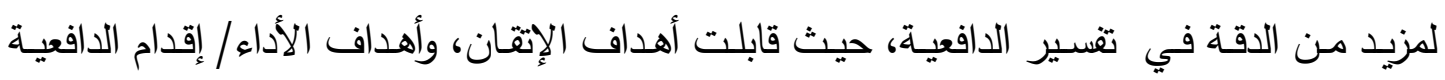

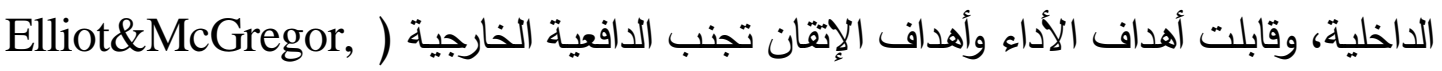
2001; Pintrich, 2000; Pintrich, 1999; Dweck,1986; Nicholls, 1984; Elliot \& . ( Trach, 2002; Darnon\& et al, 2006; Elliot et al, 2011

\section{ثانيا : السلوك الفوري اللفظي وغير اللفظي:}

يعد مصطلح السلوك الفوري من المصطلحات التي ظهرت في الآونـة الأخيرة في

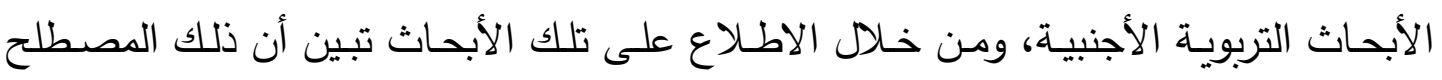


الحديث مأخوذ من مصطلح قديم جدا وهو مصطلح التواصل، ويعتبر (مهرابيان وأندرسون)

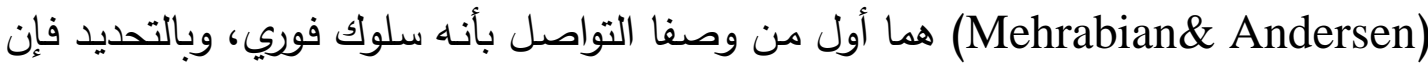

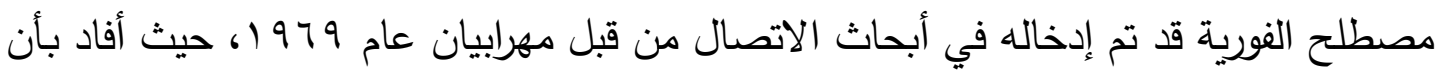
السلوكيات الفورية اللفظية وغير اللفظية تساهم في التقارب النفسي، وتسهل التواصل بين التهات الأفراد .(Mehrabian, 1971, p. 1)

وعرف(Mehrabian, 1969) السلوكيات الفورية بأنها سلوكيات التواصل التي تقرب المسافات بين الأفراد خاصـة السلوكيات غير لفظية منها ويعرفه (Andersen,1979) بأنه مجموعة السلوكيات اللفظية وغير اللفظية التي تُظهر رغبة المعلم في التقرب من الطلاب أو أولئ

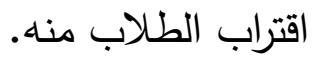

وجدير بالذكر أن مصطلح السلوك الفوري"Immediacy Behavior"في القاموس

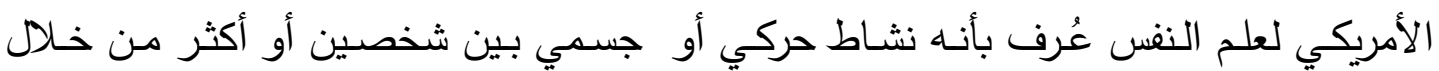
الاتصال بالعين أو الإيماءات بغرض نقل رسالة (Vanden Bos,2015,p. 525). وعُرف التواصل اللفظي وغير اللفظي في قاموس علم النفس الأمريكي بأنه نشاط يمكن

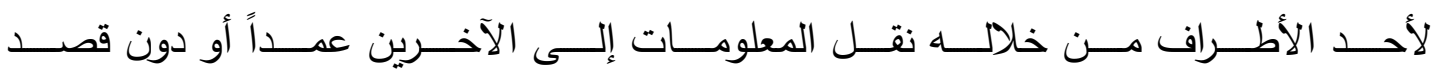
(Vanden Bos, 2015, p. 216). فمن خـلال أدبيات البحث يتضـح أن السلوك الفوري اللفظي وغير اللفظي هو نفسـه سلوكيات وفنيـات التواصل وكل مـن السلوك والتواصل نشـاط، والهـف مـن السلوك الفوري والتواصل بنوعيهما اللفظي وغير اللفظي هو نقل الرسائل والمعلومات. لذلك ستقوم الباحثة في

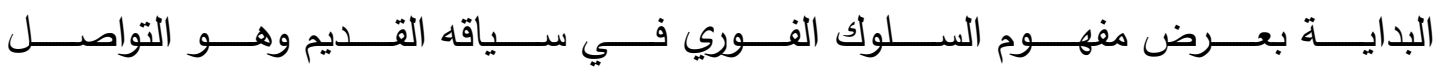
.(Vanden Bos, 2015; Mehrabian, 1971)

\section{التواصل communication}

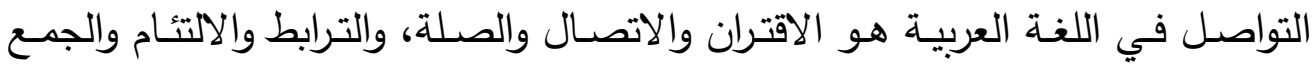

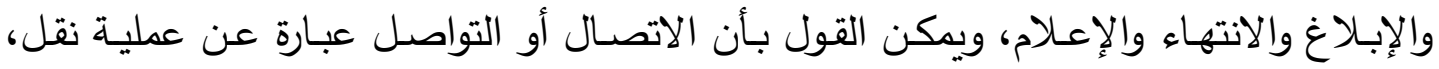

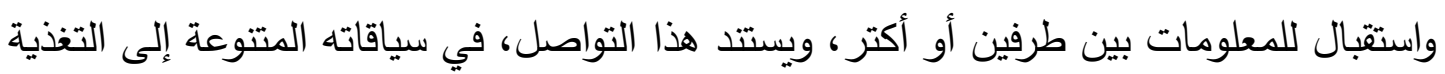

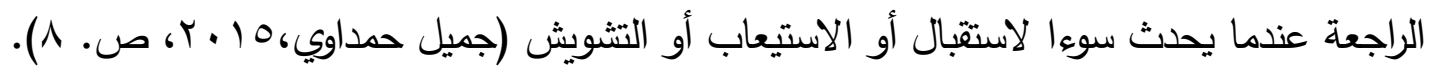

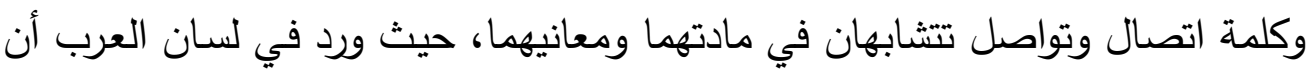
كلمة اتصال من مادة وصل، وكلمة تواصل أيضا من مادة وصل؛ مما يعني أن أصل الكلمتين واحد. 
ويعرف علماء التربية الاتصال بأنه عملية بواسطتها يمكن نقل الأفكار والتغيير الذي هي

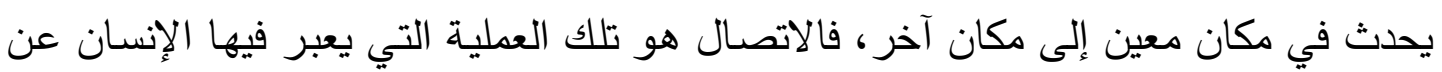

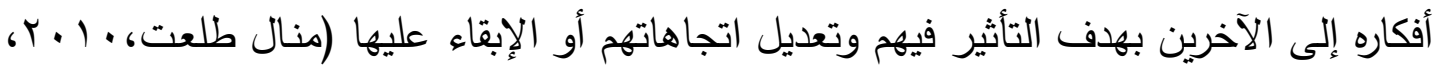

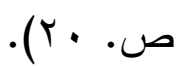

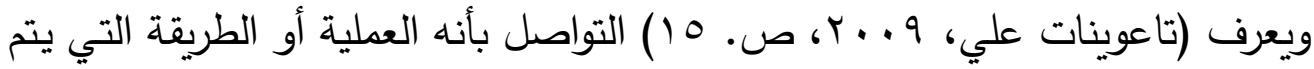

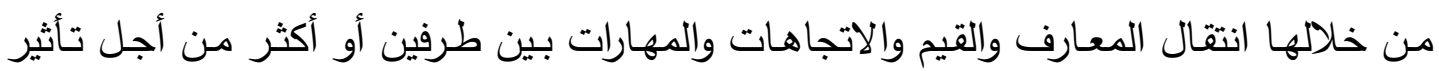

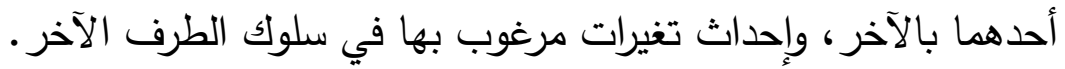

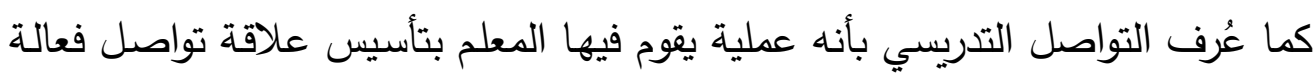
وانفعالية مع المتعلم مع المتعلم حتى يكون لاى المتعلم فرصة إنجاز النجاح الأمثل في البيئة التعليمية(Richmond\& et al,2003,p. 504). وعُرّف التواصل اللفظي في معجم المصطلحات التربويـة النفسية بأنه هذا النوع من الاتصال الذي يقوم فيه المعلم فيه بإرسال الرسالة التعليمية وتوجيه المتعلم والرد على استقساراته

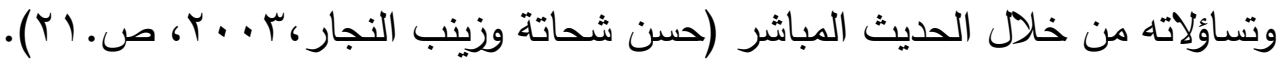
وعُرف التواصل غير اللفظي بأنه ذلك النوع من الاتصال الذي يرسل فيه المعلم رسالته

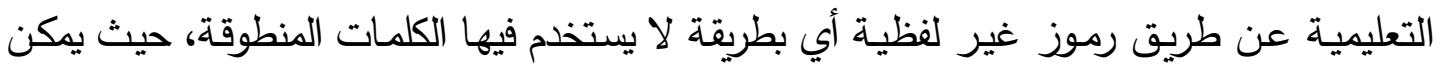
للمعلم الاعتماد على الكلمات المكتوبة والرسوم واللوحات والصور والرموز البصرية عموما، والإثارات

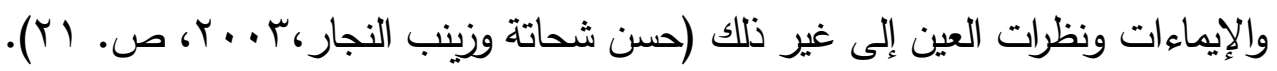
والتواصل من الناحية التربوية: عملية تحدث في الموقف التعليمي بين جميع الأطراف

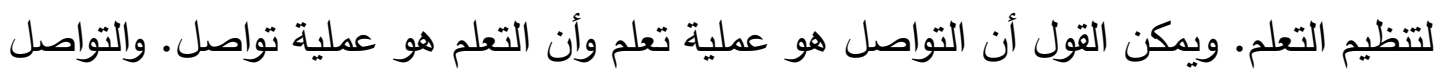

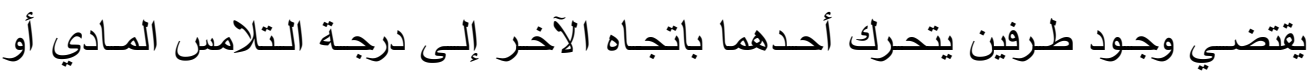

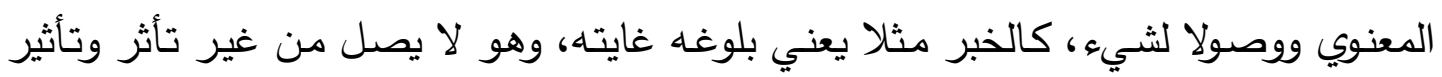

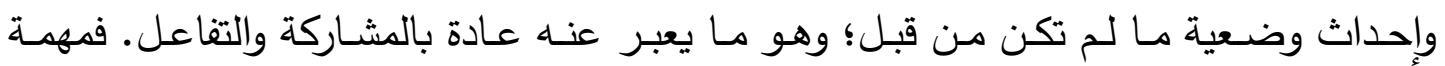

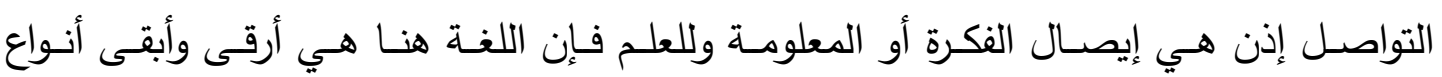
التواصل، إذ بفضلها يميز الإنسان عن سواه) تاعوينات علي، 9 . . ז، ص. ع ـ (). 
ويفضل البعض استخدام مصطلح التواصل بدلا من الاتصـال لأن التواصل يدل على

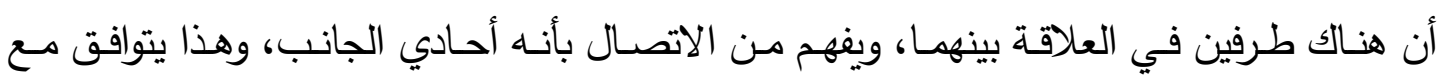

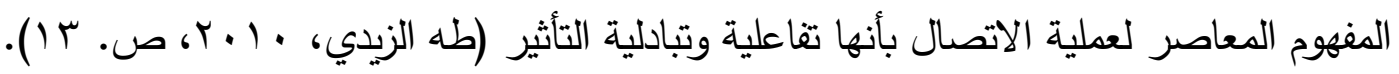

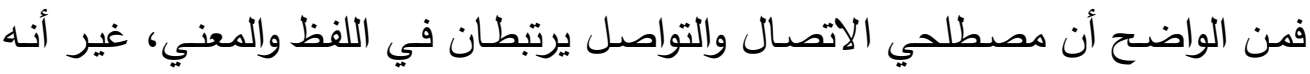

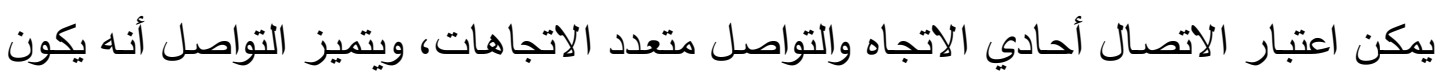
بين البشر فقط أما الاتصال فيشترك فيه البشر والآلة.

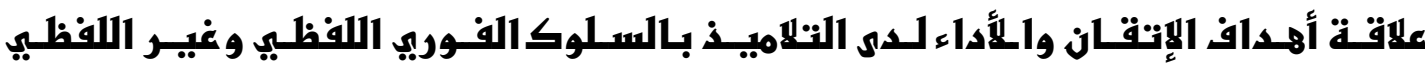

\section{لمعلميهم}

قسمت (Ames, 1992, p. 267) بيئة التعلم إلى مجموعة من الدكونات هي: المهام،

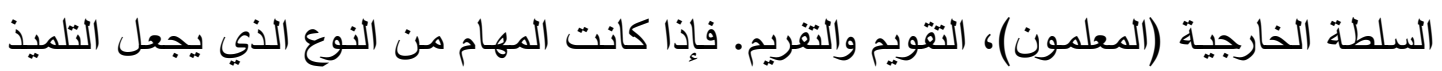

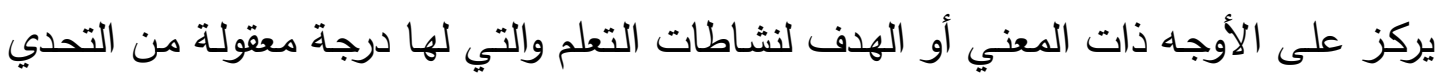

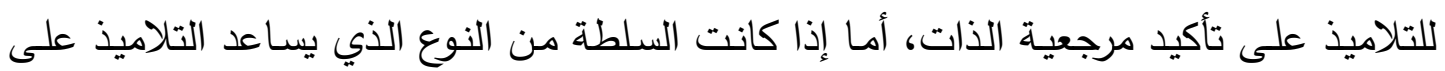

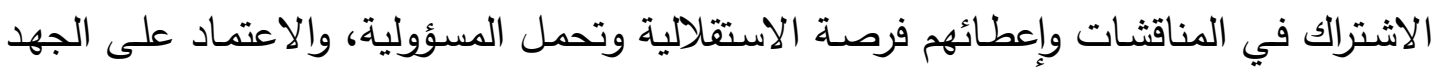

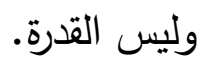

وهذا يشير إلى دور المعلم كمكون هام من مكونات بيئة التعلم، وكيف أن للمعلم القدرة

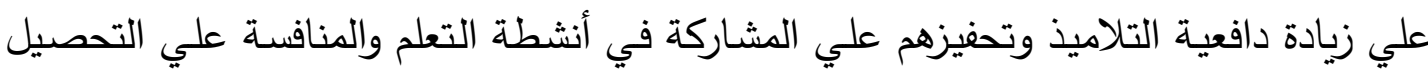

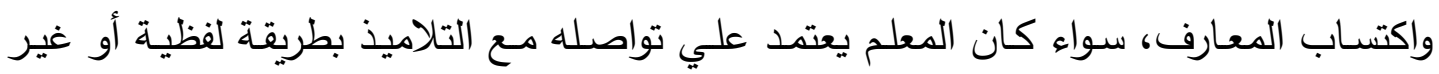
لفظية ليتمكن من تنفيذ استراتيجياته الخاصة في تحقيق الهدف من التعليم.

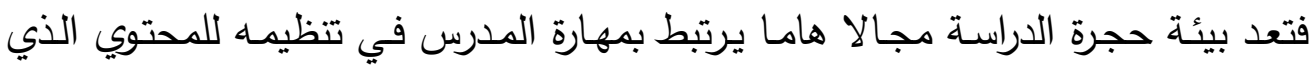

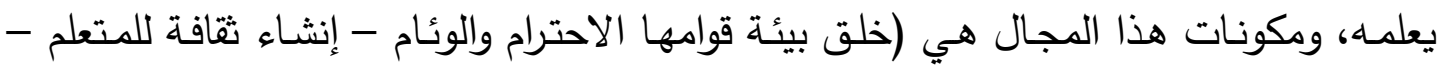

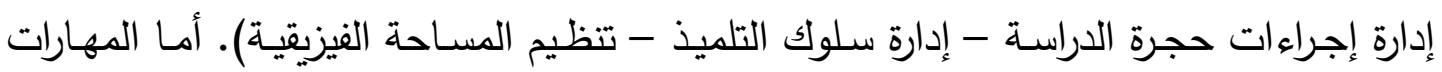
التي تساعد في دمج التلاميذ في المحتوى فهي (التوصيل والتواصل الدقيق - استخدام أساليب طرح الأسئلة والمناقشة - دمـج التلاميذ في التعلم - توفير تغذية راجعة في التعلم - إظهار المرونة والتجاوب وإثباتهما) وهذه المهارات تؤثر في كيفية خبرة التلاميذ للدحتوى سواء أكانوا

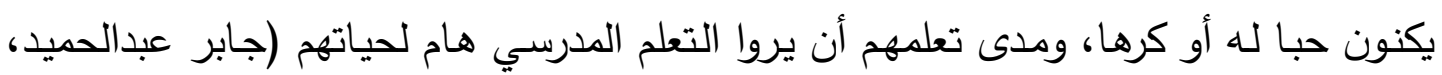

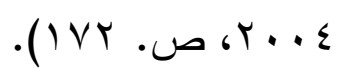


ويعد السلوك الفوري للمعلم بنوعية اللفظي وغير اللفظي جزء من البيئة التعليمية التي تؤثر في تعلُم الطالب، سواء كان هذا التأثير في التعلم المعرفي أو التعلم الانفعالي وفعالية التعلم ذاته؛ وذلك لأن السلوك الفوري للمعلم يعد من المحفزات التي تُكسب الطلاب دافعيـة

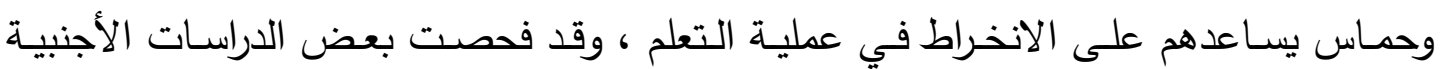
العلاقة بين السلوك الفوري للمعلم وبخاصة السلوك غير اللفظي بالدافعية لدى الطلاب، واهتم بحث(Velez\& Cano, 2012)بفص دور تواصل المعلم في دافعية الطالب ، وقد بينت (Hofer,2006)

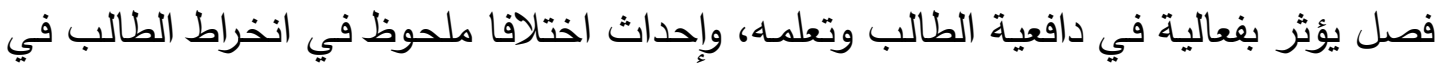
عملية التعلم، وقد قام الطلاب بقياس سلوك معلميهم الفوري اللفظي وغير اللفظي وكذلك قاموا بقياس فعاليتهم الذاتية ودافعيتهم لقيمة المهية؛ وأظهر نتائج ذلك البحث وجود علاقة اليجابية دالة بين السلوك الفوري اللفظي وغير اللفظي وفعالية الذات(In: Velez\& Cano, 2012, p. 88). فالتواصل الحقيقي هو التواصل الثقافي والوجداني الذي ينطلق من اللسان ولكنانه منبعث

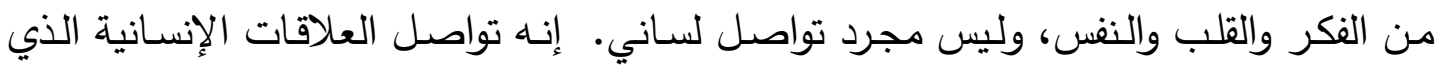

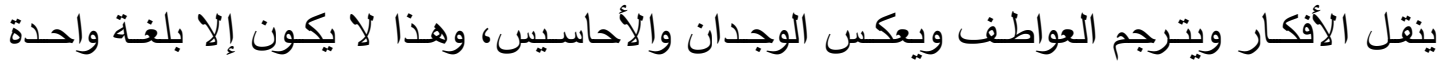

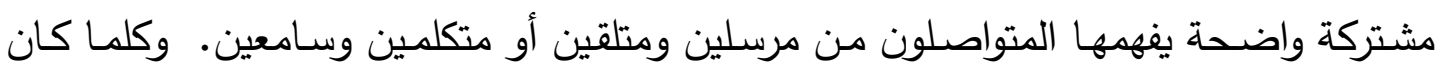

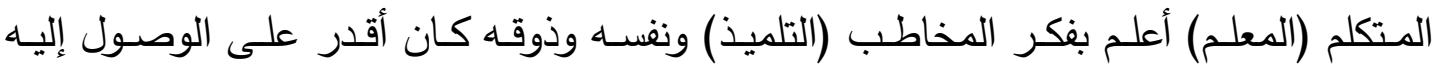

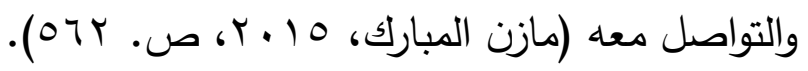

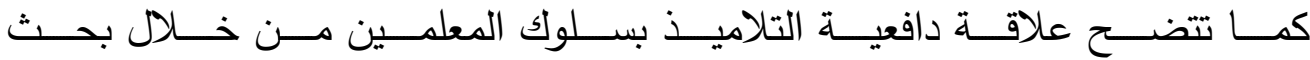
(Christophel,1990) حيث قام بفحص علاقة دافعية الطلاب بالسلوك الفوري للمعلم وتأثير تلك العلاقة على نواتج التعلم؛ وقد أظهرت النتائج أن قدرا كبيرا من السلوكيات الفئل الفوريـة للمعلم

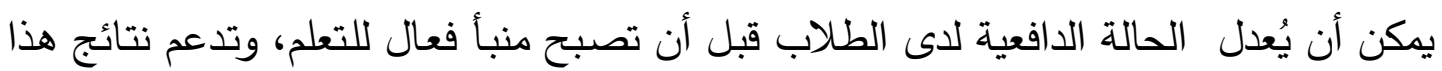

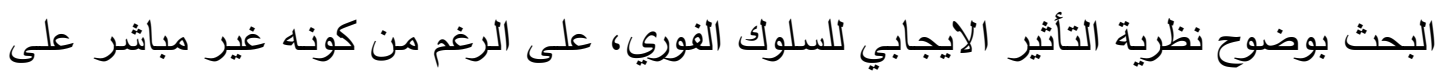

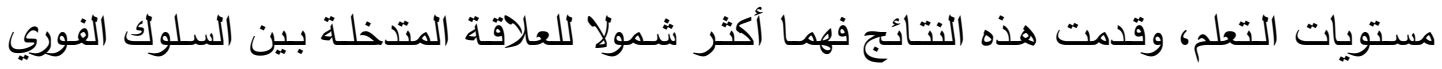
للمعلم والدافعية والتعلم. فالارتباط الإيجابي بين السلوك الفوري والدافعيـة قدم دعما للنظريــة

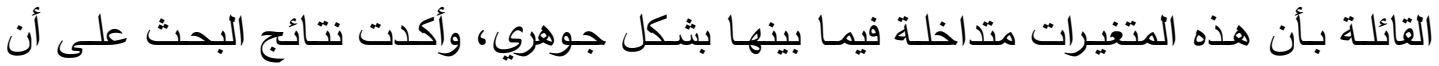

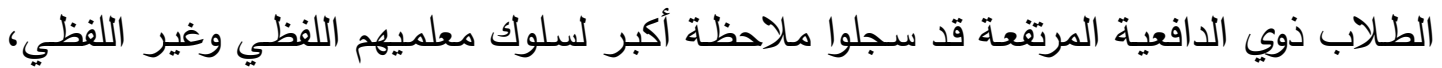
وكان هناك تباينا ملحوظا في الارتباطات البسيطة بين السلوك الفوري اللفظي وغير اللفظي. 
وقد افترض (Christophel,1990) أن استخدام المعلم للسـوك الفوري يـؤثر في

دافعيـة الطلاب للتعلم وبالتالي يؤثر في تعلم الطالب، وقد قام بفحص مستوي الطلاب في

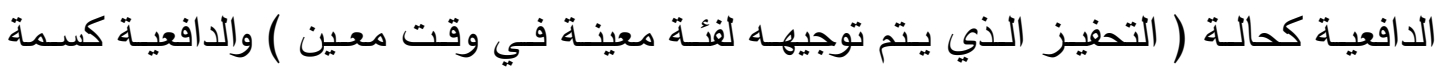
للدراسة(كتحفيز الطالب على الدراسة والتعلم ) ووجد أن السلوك الفوري ( اللفظي- غير اللفظي) كان مرتبطا ارتباطا ايجابيا بدافعية الطلاب للدراسة مع كون الدافعية كحالة أكثر ارتباطا بالفورية الفية

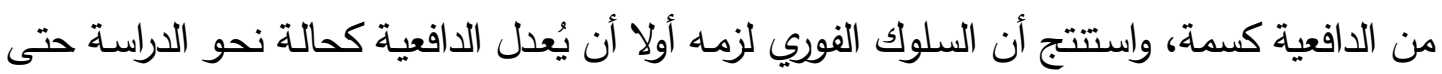
تؤثر في التعلم، واتسـاقا مـع (Christophel) وجدت (Richmond,2003) أن الفوريـة غيـر اللفظية كانت مرتبطة إيجابيا مع الدافعية كحالة للدراسة والتعلم الانفعالي والتعلم المعرفي المدرك.

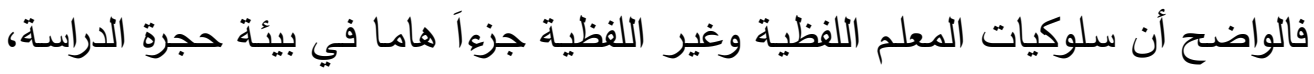
وطريقة لإدارة محتوى التعلم ودمج التلاميذ في مناخ التعلم داخل حجرة الدراسة، مما يزيد من

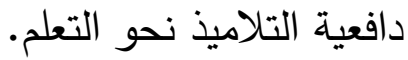
فالدفء الوجداني وروح الدعابة يسهمان في توفير بيئة آمنة منتجة، فإنهما وعلى نحو غير مباشر يزيدان من التعلم، حيث تقوم هذه البيئة الآمنة الناتجة بتوفير المساندة للتلاميذ، وهذا لهانها

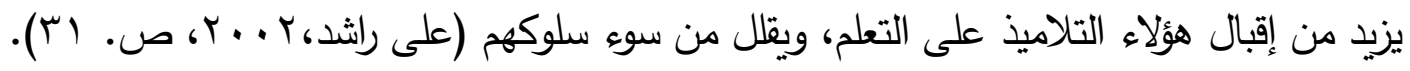

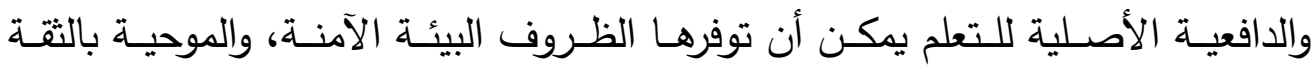
والمدعمة له، وإذا توفر للمتعلم الظروف المناسبة، والتعلم المتناسب لحاجاته وخصائصه الفريدة، وتوفير فرص التجريب والاختبار دون الشعور بالخوف من الفشل أو التهديد به. كل ذلك يضبط فيهه المتعلم تعلهـ وينمي ثتته بقدراته ويزيد إقباله على التعلم ويزيد من دافعيته للتعلم (نايفة

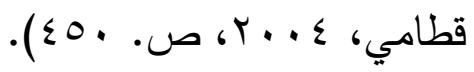
والسلوكيات اللفظية وغير اللفظية للمعلم داخل الفصل من شأنها أن تثجع التلاميذ وتحفزهم للمشاركة والرضاء النفسي والتعلم، أو تثبط هم التلاميذ وتحد من نشاطهم العام (علي

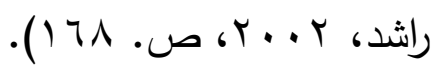

لذلك على المعلم الكفء أن يدرك السلوكيات اللفظية وغير اللفظية التي تحفز التلاميذ

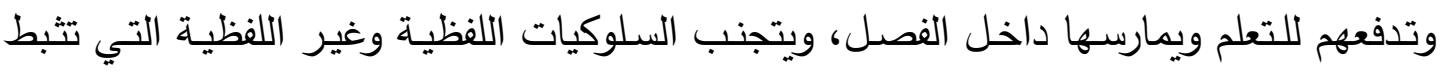
همتهم وتتلل نشاطهم. 


\section{البحوث المرتبطة بموضوع البحث الحالي:}

\section{أولاً: دراسات تناولت الأهداف الدافية للإنجاز فى ضوء النوع: -}

بحث(Broussard,2002) هدف إلى كثف العلاقة بين دافعية التلاميذ داخل الفصل

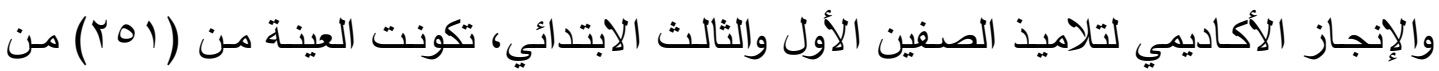
تلاميذ وتلميذات الصفين الأول والثالث الابتدائي، وتم الاستعانة بمقياس "Harter,1981"

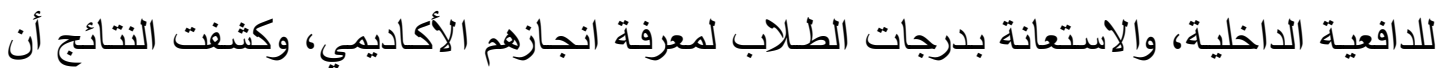

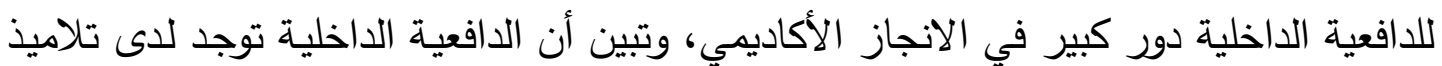
الصف الثالث بمستوى أعلى من وجودها في الصف الأول.

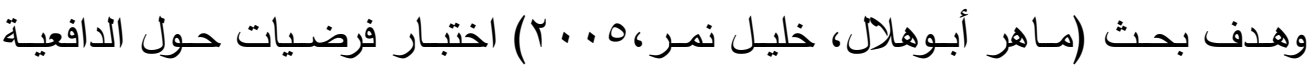

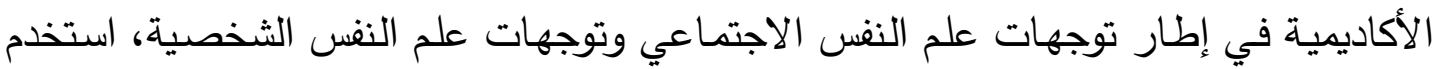

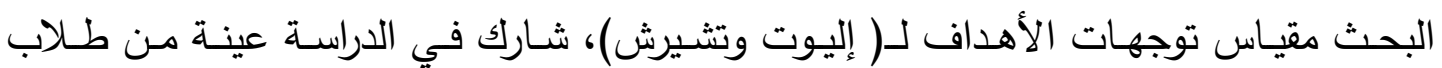
وطالبات المدارس وعينة من طلاب وطالبات الجامعة، وقد بينت نتائج البحث وجود فروق بين الذكور والإناث في تكوين أهداف الإتقان والأداء والعلاقة بينهما بالنسبة للمرحلة الجامعية، وعدات وجود فروق بين الذكور والإناث في أهداف الإتقان والأداء بالنسبة للمرحلة الابتدائية. وهدف بحث (على بن سليمان، V . . Y) إلى معرفة مستوى الدافعية الداخلية والخارجية

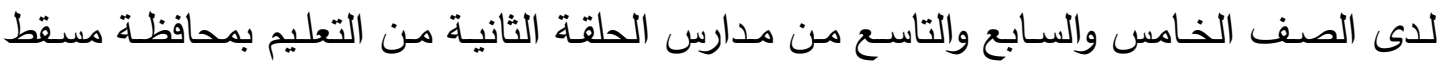
بسلطنة عمان وعلاقتهما بالتحصيل الدراسي الذي يمثل المجموع الكلى للمواد الدراسية، تكونت

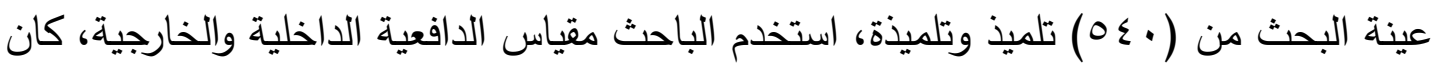

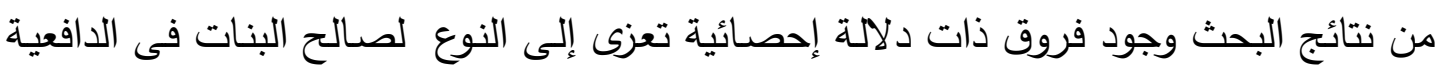
الداخلية، وعدم فروق ذات دلالة تعزى للنوع في الدافعية الخارجية. وهدف بحث (Rahmani, 2011)هدف البحث لدراسة علاقة أهداف الانجاز وتقدير

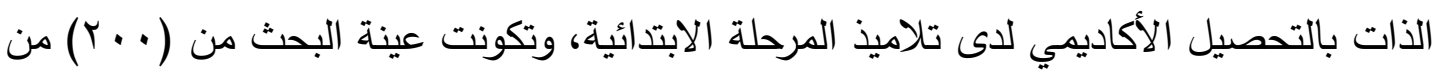

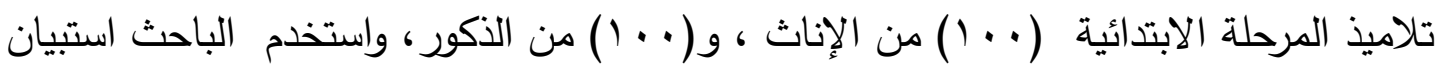

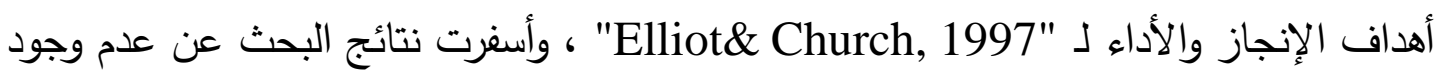
فروق بين الذكور والإناث فى أهداف الإتقان. 
أما بحث(Mirzaei, et al, 2012) فهدف إلى فحص العلاقة بين أهداف الإنجاز

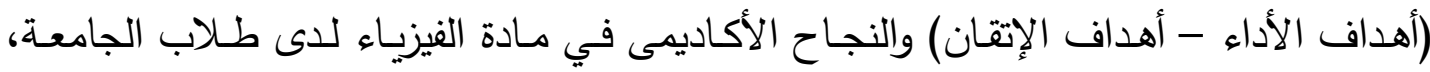

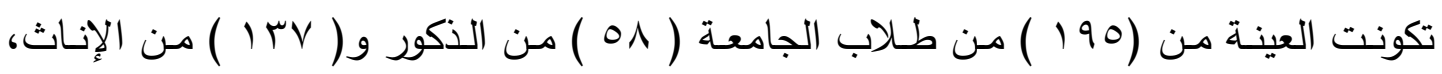

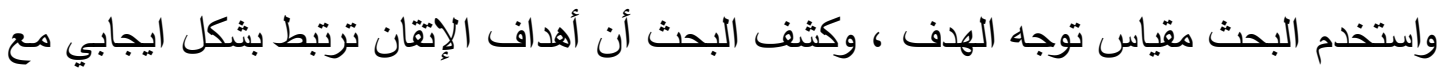

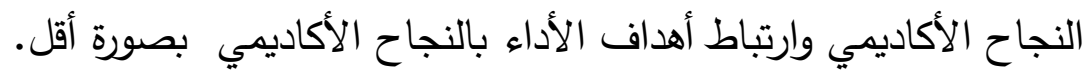

ثانيـا : دراسـات تناولت العلاقة بـين الأهداف الدافيـة للإنجـازوالسلوك الفوري اللفظي وغير

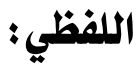

بحث (Furlich\& Dwyer,2007) هدف البحث إلى معرفة العلاقة بين السلوك

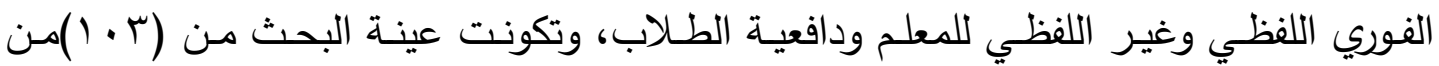

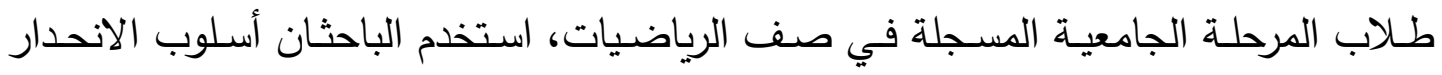

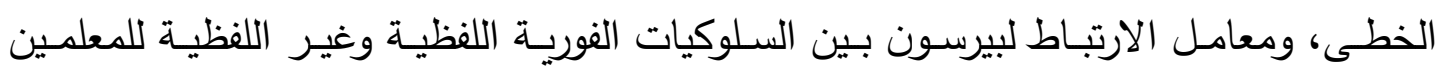

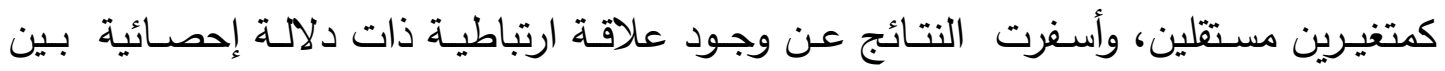

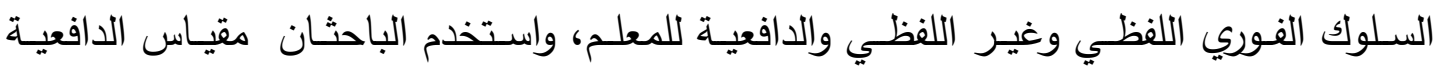

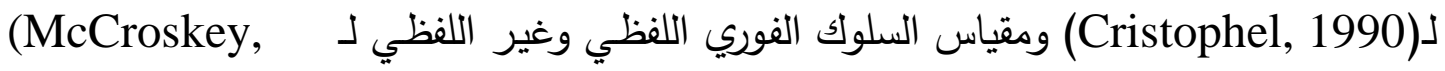

. Richmond\& Gorham,1987) أما بحث(Tum, 2010)أُجري فى تركيا وكان الهدف منه معرفة العلاقة بين السلوك الفوري اللفظي وغير اللفظي للمعلم ودافعية الطلاب الأجانب لتعلم اللغة التركية، تكونت التهان العان العينة

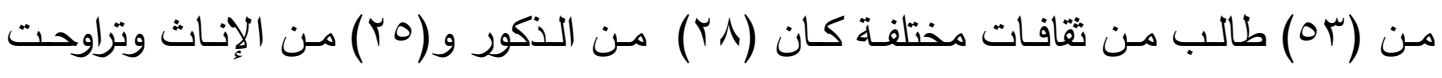

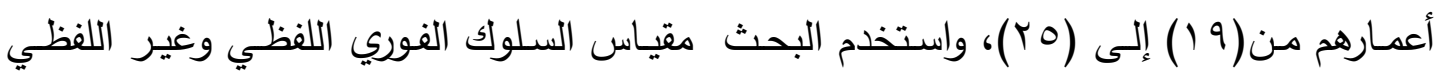

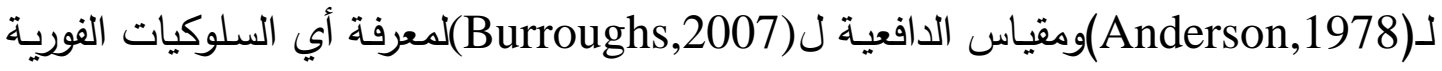

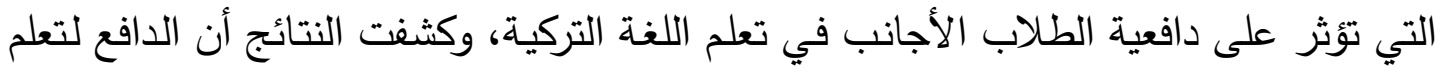

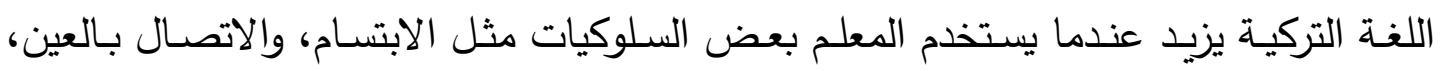
وتغيير نبرة الصوت.

وهدف بحث( Johan,2012) إلى معرفة العلاقة بين السلوك الفوري اللفظي وغير

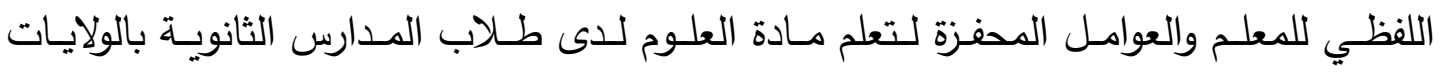

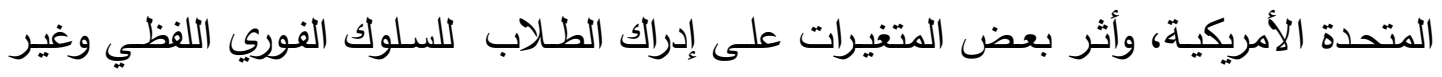

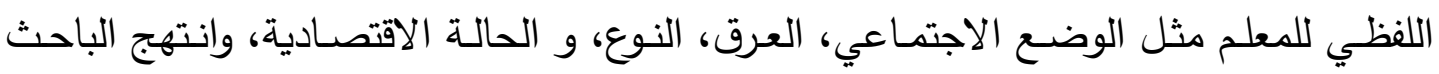

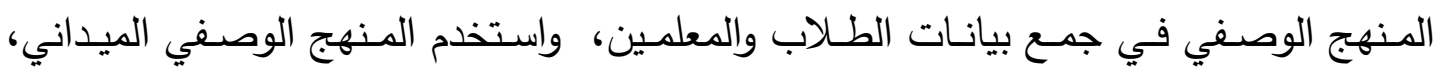




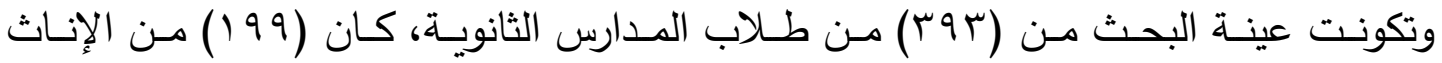

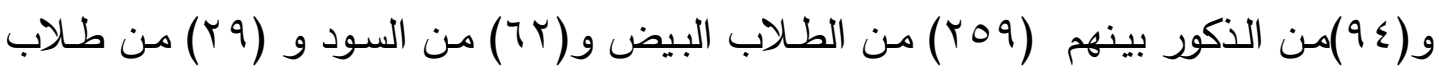

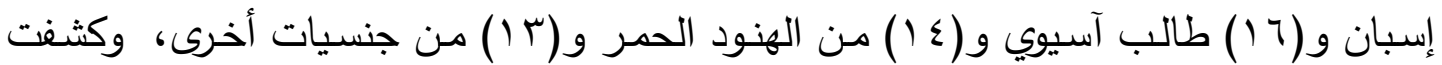

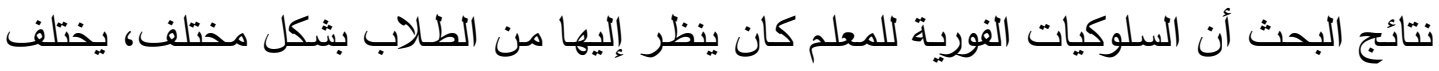

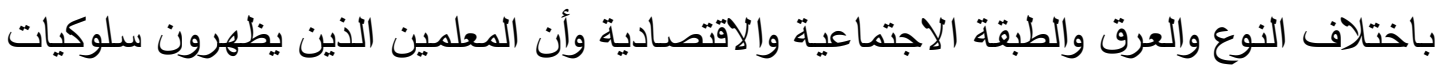

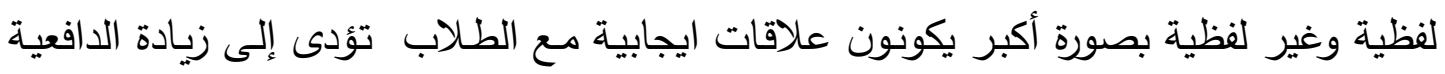
لاى الطلاب وزيادة الحافز في التحصيل الدراسي لمادة العلوم. بينما هدف بحث (Furlich, 2016) هدف إلى دراسـة العلاقة بين دافعية الطلاب

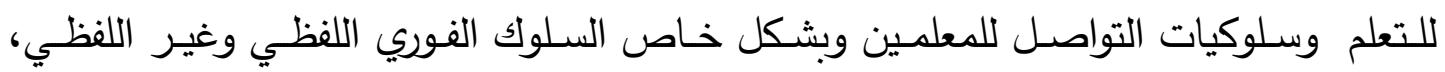

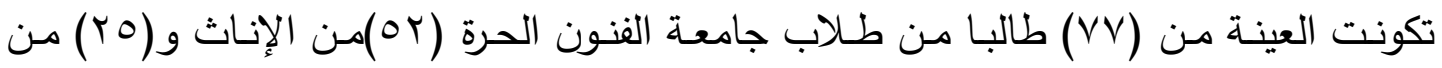
الذكور ، واستخدم الباحث مقياس(Christophel,1990) للدافعية ومقياس (Gorham,1988)

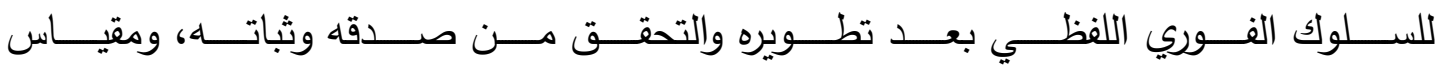
(McCroskey\& Richmond, Gorham, 1987) للسلوك الفوري غير اللفظي بعد تطويره، واعتمد البحث في تحليل البيانات علي أسلوب الانحدار الخطي الذي كثف عن وجود

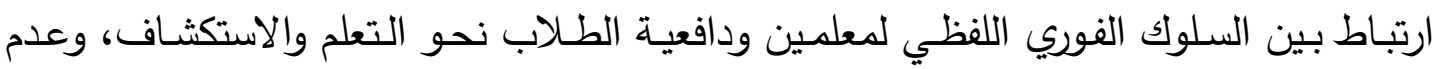
وجود علاقة بين السلوكيات الفورية غير اللفظية للمعلمين ودافعية الطلاب نحو التعلم.

يتضح من نتائج الدراسات التى تناولت الفروق في الأهداف الدافعية للإنجاز في ضوء

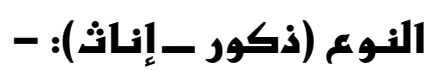

يتضح وجود اتساق إلى حد ما في نتائج الدراسات التي تتاولت الفروق بين الذكور والإناث فى التى

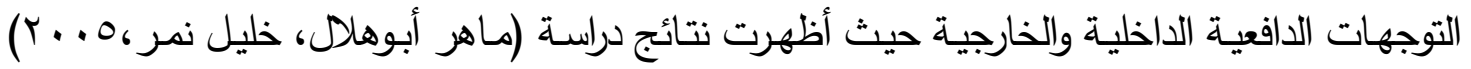

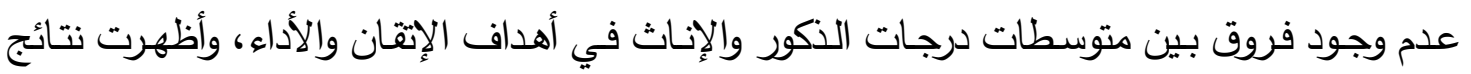

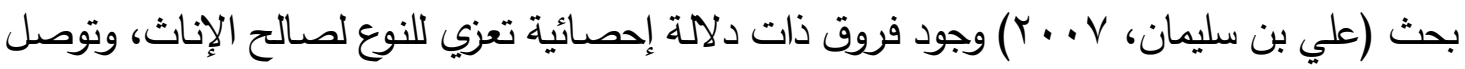
بحث (Rahmani, 2011) إلى عدم وجود فروق بين الذكور والإناث في أهداف الإتقان.

\section{يتضح مز نتنائج الدراسات التني تنـاولت الأهداف الدافعيـة للإنجـاز والسلوكالفوريي}

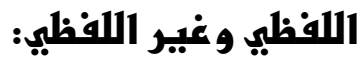
كثفت نتائج بحث(Furlich\& Dwyer, 2007)عن وجود علاقة ايجابية بين إدراك الطلاب للسلوك الفوري غير اللفظي ودافعية الطلاب للتعلم، وتوصل بحث 


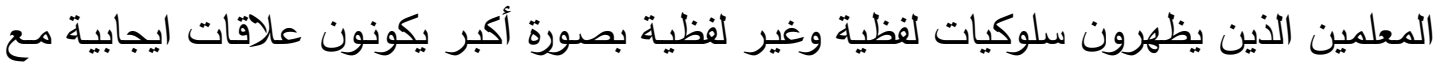

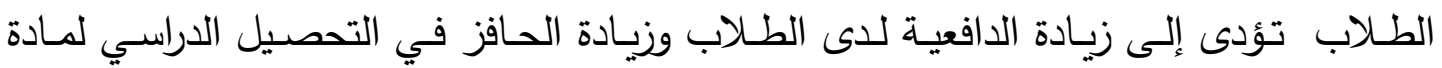
العلوم،كثف بحث(Furlich, 2016) عن وجود ارتباط بين السلوك الفوري اللفظي لمعلمين

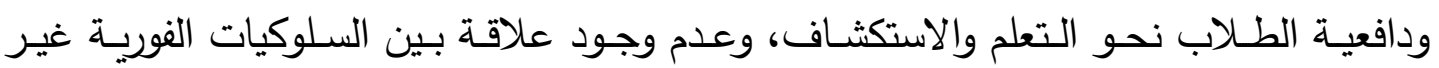
اللفظية للمعلمين ودافعية الطلاب نحو التعلم.

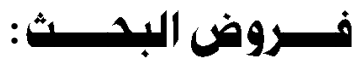

فى ضوء نتائج الدراسات والبحوث السابقة يمكن صياغة الفروض التالية: 1- يمكن التتبؤ بأهداف الإتقان لتلاميذ الصفين الخامس والسـادس الابتدائي من خـلال إدراكهم للسلوك الفوري اللفظي وغير اللفظي لمعلميهم. باهن. ץ- يمكن التتبؤ بأهداف الأداء لتلاميذ الصفين الخـامس والسـادس الابتدائي مـن خـلال إدراكهم للسلوك الفوري اللفظي وغير اللفظي لمعلميهم. r- لا توجد فروق دالة إحصائيا بين متوسطات درجات البنين والبنات من تلاميذ الصفين الخامس والسادس الابتدائي في أهداف الإتقان والأداء.

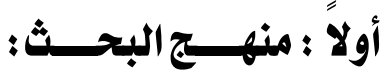
انطلاقاً مـن طبيعـة البحـث، والأهداف التي يسـعى البحث لتحقيقها والنتائج المـراد

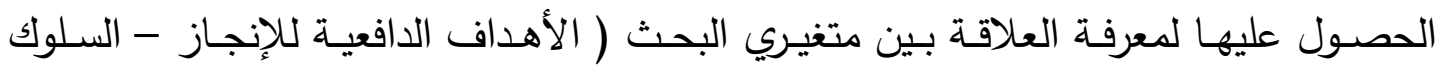

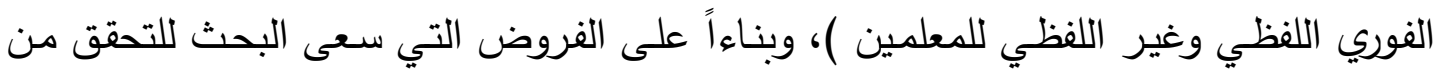
صحتها، فقد استخدت الباحثة المنهج الوصفي.

\section{ثانيا : عينــــة البحــــ}

تم اشتقاق عينة الاستطلاعي لبحث الحالي من تلاميذ المرحلة الابتدائية من الصفين

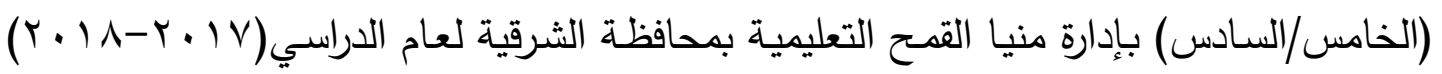

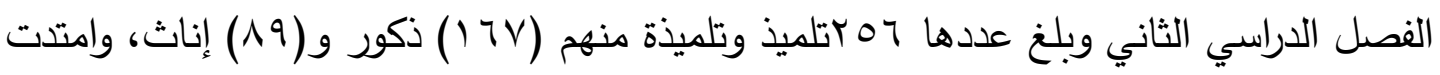

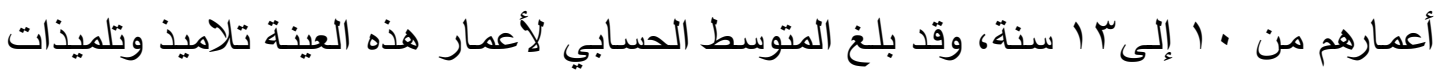

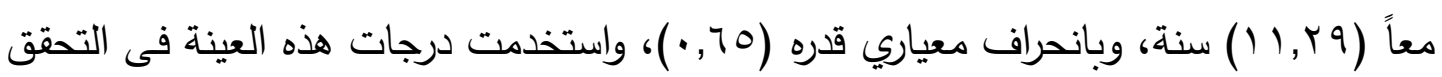
من صدق وثبات أدوات البحث. 


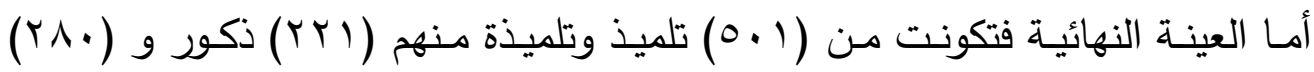

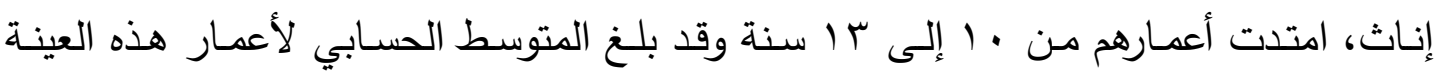

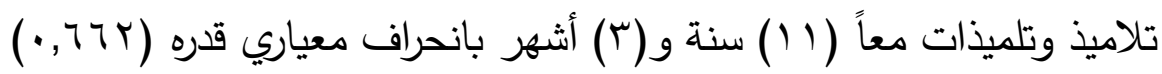

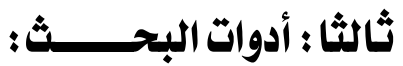

\section{1- مقياس أهداف الإنقان والأداء (إعداد الباهثة)}

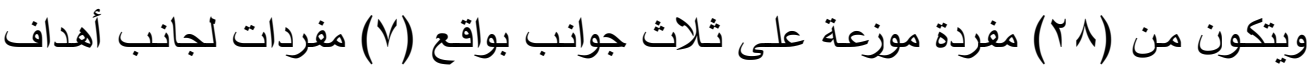

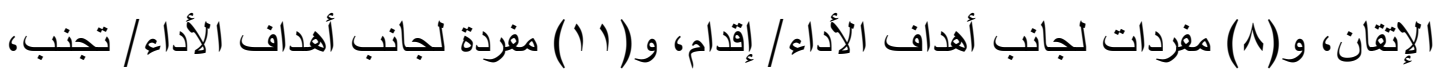

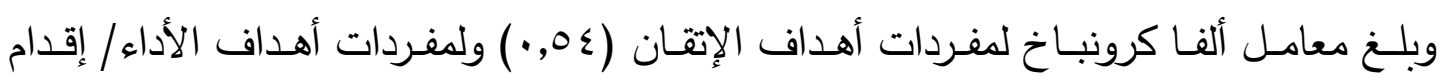

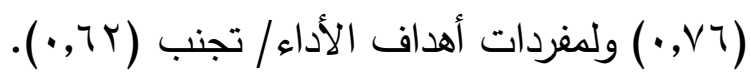

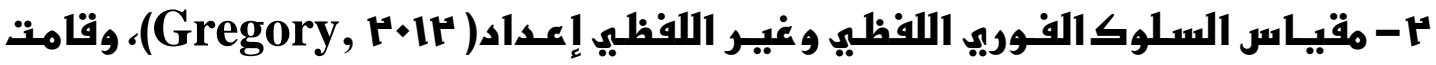

\section{الباهثة بـترجمته وتنقنينه.}

تكون المقيـاس مـن جـانبين، الأول هو السـوك الفوري اللفظي، والثاني هو السلوك

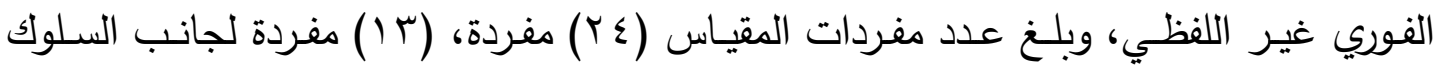
الفوري اللفظي، (1) (1) مفردة لجانب السلوك الفوري غير اللفظي، وبلغ معامل ثبات المقياس (ألفا- كرونباخ)

\section{رابعا : إجـــــراءات البحـــــ}

1- قامت الباحثة بتجميع الإطار النظري والدراسات السابقة المتعلقة بموضوع البحث. r-وفي ضوء الإطار النظري والنظريات السابقة، قامت الباحثة بإعداد مقياس أهداف الإنتان الإنقان

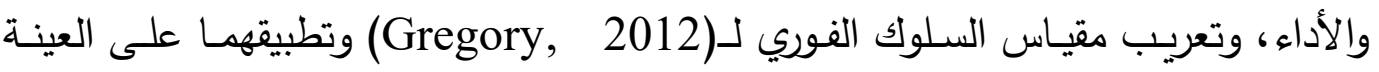

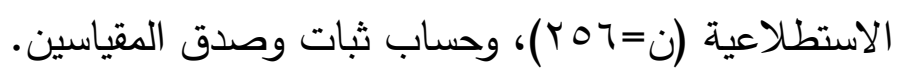

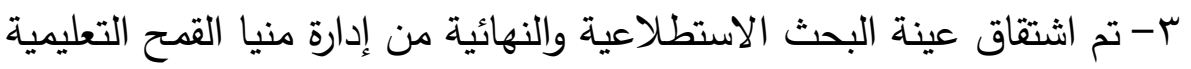

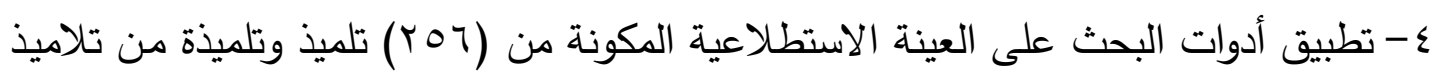

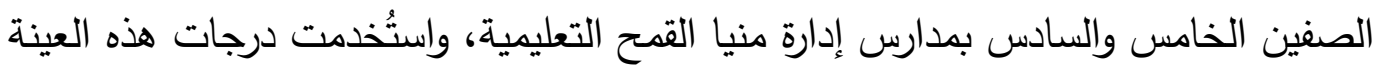

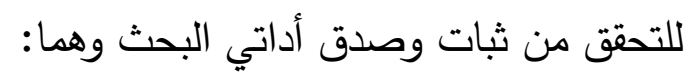

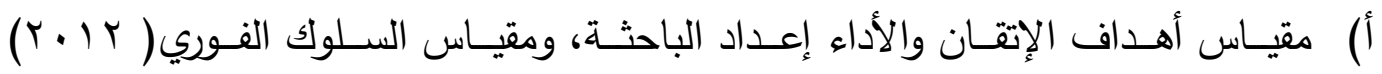
(Gregory, 
0- بعد تقنين أداتي البحث والتأكد من جودة ثباتهما وصدقهما تم تطبيقهما على العينة النهائية المكونة من (1. (0) تلميذ وتلميذة من تلاميذ الصفين الخامس والسادس الابتدائيين بمدارس إدارة منيا القمح التعليمية، واستخدمت هذه العينة للتحقق من صحة الفين الفروض.

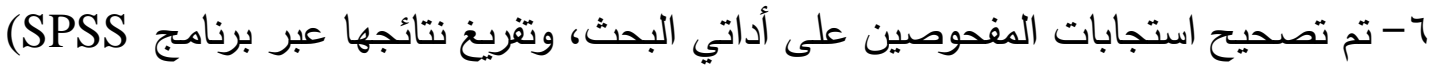
$16,0)$

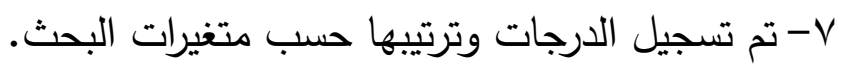

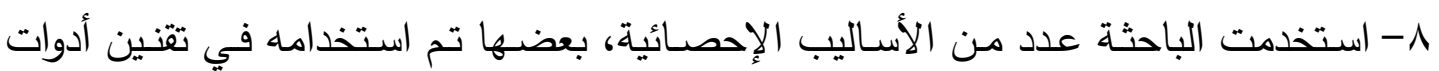
البحث (الثبات - الاتساق الداخلي - الصدق)، والبعض الآلئ الآخر من الأساليب الإحصائية تم

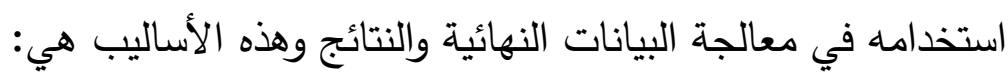

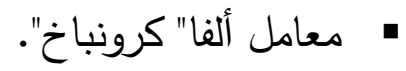

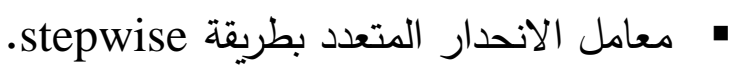

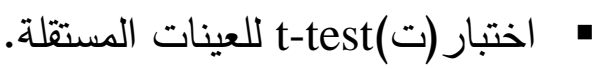

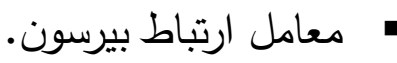
• - التحليل العاملي من الدرجة الثانية.

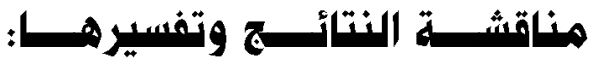

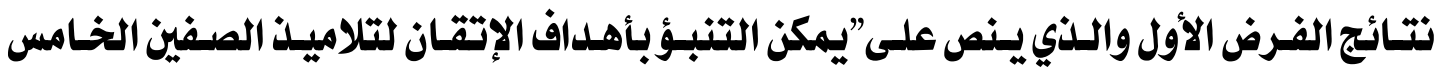
والسادس الابتدائي من خلال إدراكهم للسلوك الفوري اللفظي وغير اللفظي لمعلميهـ".

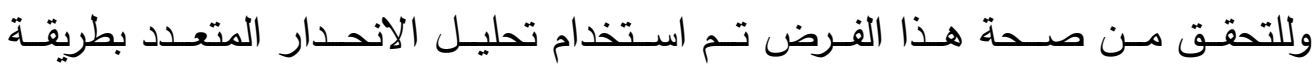
Stepwise Multiple Regression الإتقان لدي تلاميذ الصفين الخـامس والسـادس الابتدائي، حيث كـان مربع معامل الارتباط

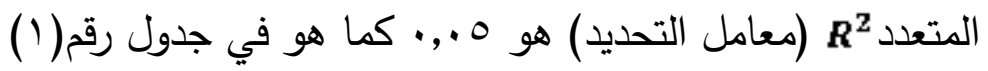
جدول ( ) تحليل الانحلار المتعدد للتنبؤبأهداف الإتقان من جوانب السلوك الفوري (ن= (0.1)

\begin{tabular}{|c|c|c|c|c|c|}
\hline $\begin{array}{c}\text { التحديل معامل } \\
R^{2}\end{array}$ & قيمةل(ف) & متوسط & الحرية & مجموع المربعات & مصلدر التباين \\
\hline \multirow{2}{*}{$\cdot, \bullet$} & \multirow{2}{*}{$* * \boldsymbol{*}, \boldsymbol{r} \cdot \square$} & rm, r. & 1 & rrI, r. & المنسوب إلى الانحلدار \\
\hline & & $9,+4$ & $\varepsilon 99$ & $\sum 7 \gamma \cdot, r q$ & المنحرف عن الانحدار (البواقي) \\
\hline
\end{tabular}




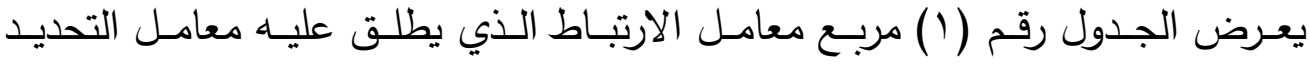
ويمثل نسبة التباين المفسر في درجات المتغير المستقل (السلوك الفوري) بواسطة المتغير

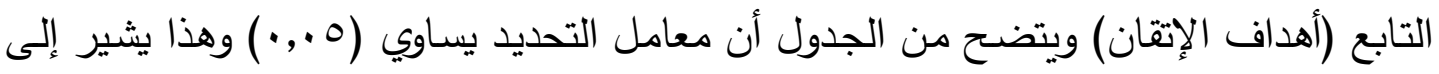
أن المتغير المستقل (أهداف الإتقان يفسر ه\% من الإن التباين في درجات المتغير التابع (أهداف

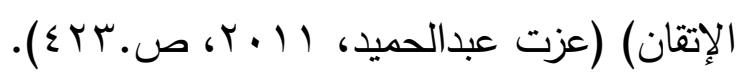

جدول (r) نتائج النبؤبأهداف الإتقان لدى التلاميل من السلوك الفوري غير اللفظي للمعلمين

\begin{tabular}{|c|c|c|c|c|}
\hline قيمة (ت) & معامل الانحلار & الخطيار & معامل الانحلار & المتفيرات المستقلة \\
\hline$* * Y Y, \leq Y$ & $\bar{\square}$ & $\cdot, 91$ & $\mathrm{MI}, \wedge \mathrm{A}$ & المقدار الثابت \\
\hline$* * \xi, q \gamma$ & $\cdot, r r$ & •, & $\bullet, I r$ & السلوك الفوري غير اللفظي \\
\hline
\end{tabular}

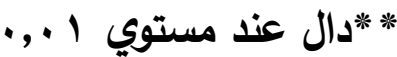

يتضح من الجدول رقم (r) أنه يمكن التتبؤ بأهداف الإتقان لتلاميذ الصفين الخامس

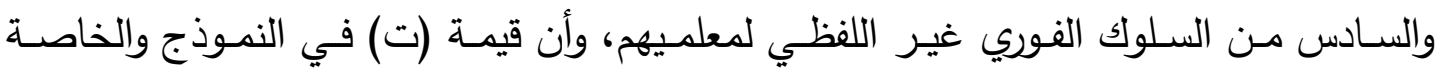

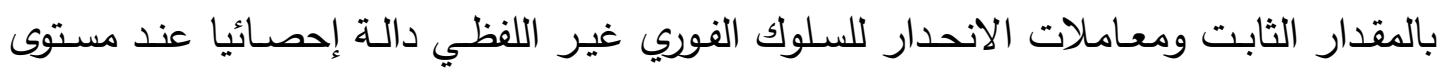

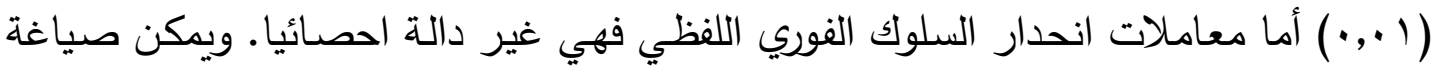
معادلة التنبؤ لأهداف الإتقان من السلوك الفوري غير اللفظي علي النحو التالي:

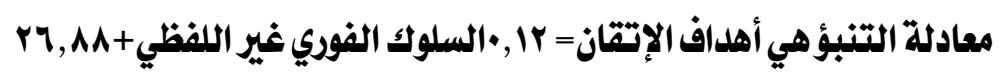

وتـلال النتائج على أنسه: يمكن التتبؤ بأهداف الإتقان لدي تلاميذ الصفين الخامس

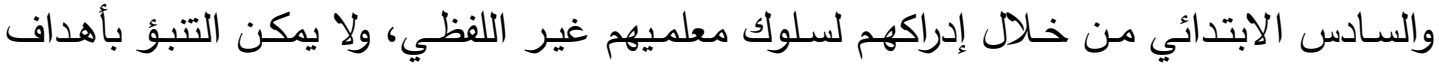

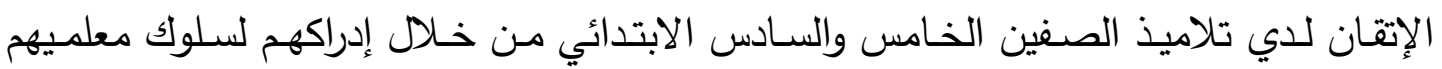
اللفظي، وبذلك يتحقق الفرض الثاني جزئيا. ويفسر ذلك بأن التتبؤ بأهداف الإتقان من خـال إدراكياك التلاميذ للسلوك الفوري غير

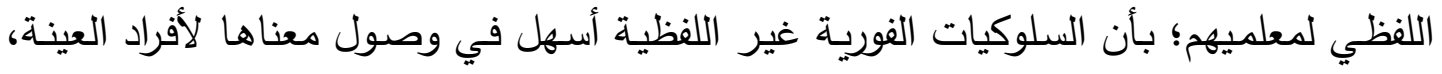

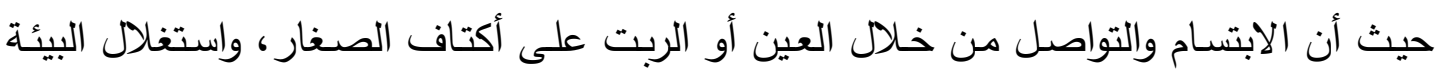

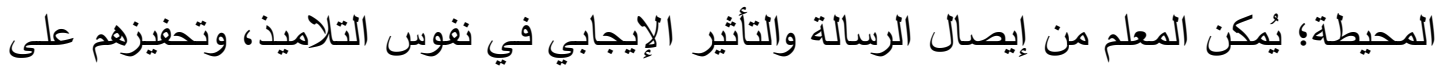

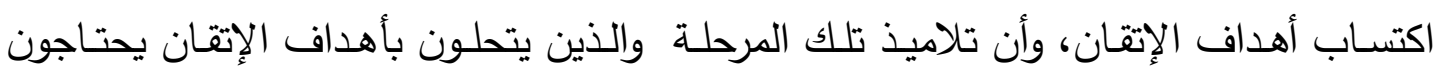


للشعور بالثقة والأمن والطمأنينة؛ حتى يشجع تعلمه ويزيد إقباله على التعلم، ويزيد من كفاءته وإتقانه للمهارات الجديدة التي تعلمها.

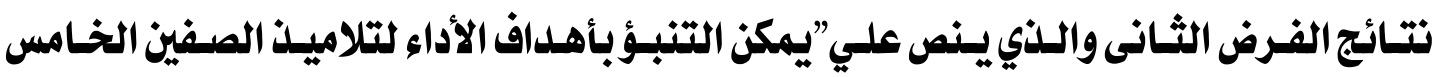
والسادس الابتدائي من خلال إدراكهم للسلوك الفوري اللفظي وغير اللفظي لمعلميهم".

Stepwise وللتحقق من صحة هذا الفرض تم استخدام تحليل الانحدار المتعدد بطريقة Multiple Regression تلاميذ الصفين الخامس والسادس الابتدائي، حيث كان مربع معامل الارتباط المتعدد

التحديد) هو ( +, • كما هو في جدول رقم (r)

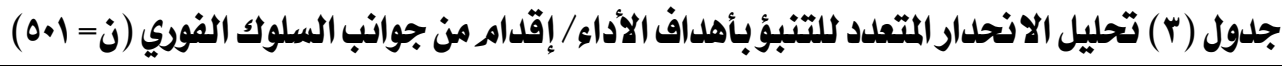

\begin{tabular}{|c|c|c|c|c|c|}
\hline $\begin{array}{c}\text { التحديل معامل } \\
R^{2}\end{array}$ & قيمة ودلاتلها & متوسط المربعات & الحرية & مجموع المربعات & مصلدر التباين \\
\hline \multirow{2}{*}{$\cdot,+1$} & \multirow{2}{*}{$* * 0, \vee r$} & $r \cdot 0, r q$ & 1 & $r \cdot 0, r q$ & المنسوب إلى الانحلار \\
\hline & & ro, 19 & $\$ 99$ & $1 \vee q \cdot 9,98$ & المنحرف عن الانحدار (البواقي) \\
\hline
\end{tabular}

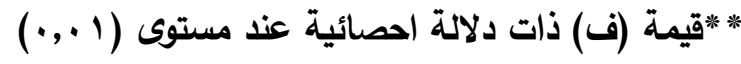

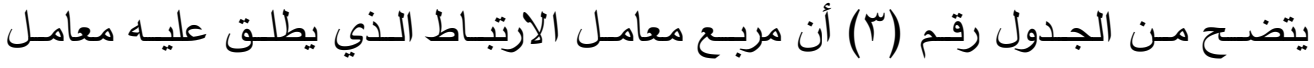

التحديد R ويمثل نسبة التباين المفسر في درجات المتغير المستقل (السلوك الفوري) بواسطة المتغير التابع (أهداف الأداء/ إقدام) ويتضـح من الجدول أن معامل التحديد يسـاوي (1 (., ) وهذا يثير إلى أن المتغير المستقل (السلوك الفوري) يفسر ا \% من التباين في درجات المتغير

$$
\text { التابع (أهداف الأداء/ إقدام). }
$$

\begin{tabular}{|c|c|c|c|c|}
\hline قيمة (ت) ودلالتها & معامل الانحلدار & المالخياري & معامل الانحدار & المتفيرات المستقلة \\
\hline$* * 17, \mathrm{rq}$ & 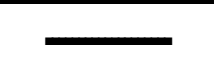 & $1, V Y$ & $r v, 91$ & المقدار الثابت \\
\hline$* Y, r q$ & $\cdot, 11$ & $\cdot, \cdot \xi$ & $\cdot, \bullet \wedge$ & السلوك الفوري اللفظي \\
\hline
\end{tabular}

جدول (飞) نتائج التنبؤبأهداف الأداء / إقداه للدي التلاميذ من السلوك الفوري اللفظي للمعلمين

"دال عند مستوى ه .,

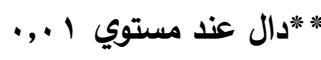

ويتضـح من جدول رقم (ع) أن قيمة (ت) في النموذج والخاصـة بالمقدار الثابت د دالة

إحصائنا عند مستوى( ( ,.•) ومعامل انحدار السلوك الفوري اللفظي دال إحصائيا عند مستوى دلالة (0, •)، كما تدل النتائج على ما يلي: 
يمكن التتبؤ بأهداف الأداء/ إقدام من خـلال السلوك الفوري اللفظي، ولا يمكن التتبؤ بأهداف الأداء/إقدام من خلال السلوك الفوري غير الاداه اللفظي. ويمكن صياغة معادلة التتبؤ لأهداف الأداء/ إقدام من السلوك التول الفوري اللفظي علي النحو التالي: - n

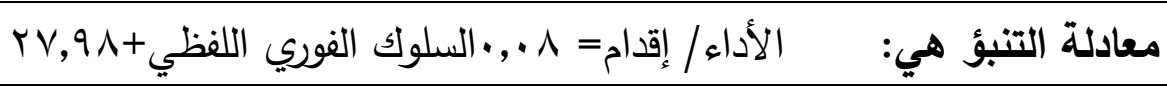

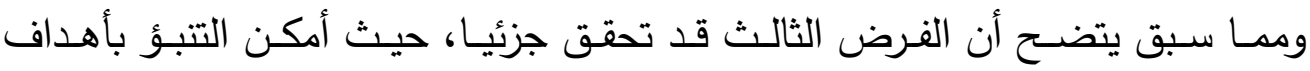

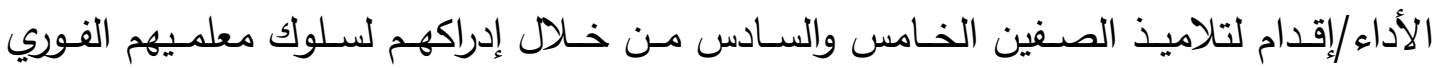

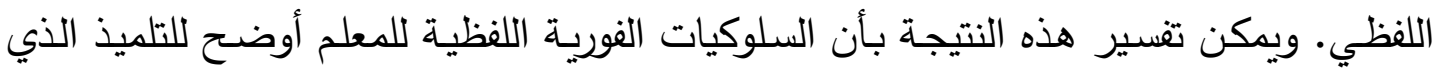

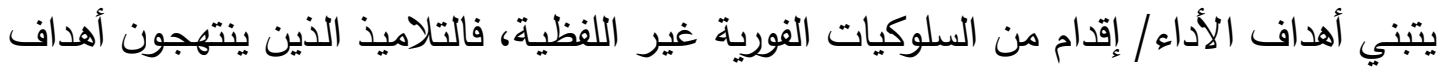

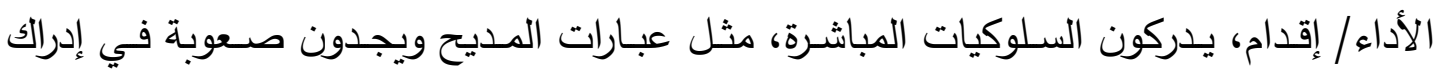
السلوكيات غير المباشرة مثل التواصل بالعين والإيماءات.

\section{نتائج الفرض الثالثوالذي ينص علي"لا توجد فروق دالة إحصائيا بـين متوسطات درجـات البـنين}

\section{والبنات من تلاميذ الصفين الخامس والسادس الابتدائي في أهداف الإتقان والأداء”.}

للتحقق من صحة هذا الفرض تم استخدام اختبار (تT)T-test لدي عينتين مستقلتين

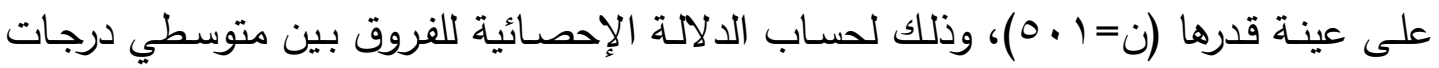

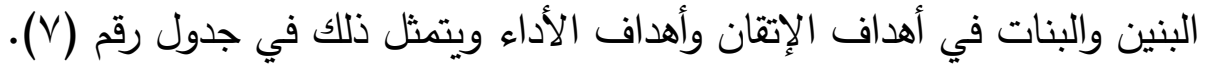
جدول (V) : نتائج اختبا (ت) لدلالة الفروق بين متوسطي درجات البنين والبنات في أهداف الإتقان والأداء

\begin{tabular}{|c|c|c|c|c|c|c|}
\hline \multirow{3}{*}{ قالإحصائية } & \multirow{3}{*}{ درجات الحرية } & \multirow{2}{*}{\multicolumn{2}{|c|}{ 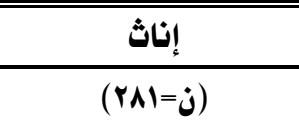 }} & \multirow{2}{*}{\multicolumn{2}{|c|}{ ذكور }} & \multirow{3}{*}{ المتفير } \\
\hline & & & & & & \\
\hline & & الالأحراف & المتوبط المسابي & الانحراف المعياري & المتوسط & \\
\hline$\cdot, 09-$ & $\$ 99$ & $r, I r$ & HI, VY & $r, 10$ & $r, 71$ & أهداف الإتقان \\
\hline 1,00 & $\$ 99$ & $7, r r$ & rI, $7 \mathrm{r}$ & $0, V_{r}$ & rr,OI & أهداف الأداء /إقداه \\
\hline$\cdot, \vee \vee$ & $\$ 99$ & $v, 7 \varepsilon$ & $r v, 0$. & $7, V \varepsilon$ & $r \Lambda, \cdot 1$ & أهداف الأداء/تجنب \\
\hline
\end{tabular}

مناقشة نتائج الفرض الثالث:

يتضح أن الفرض الثالث قد تحقق كليا، وقد اتفقت بعض نتائج هذا الفرض مع بحث (Rahmani,2011) 


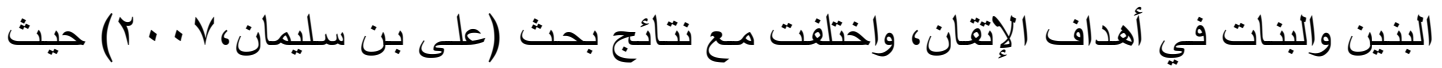

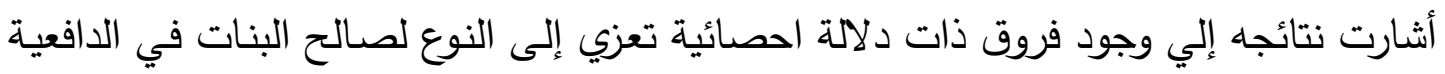

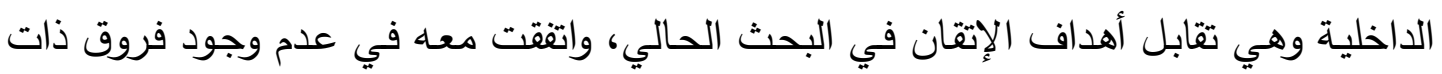

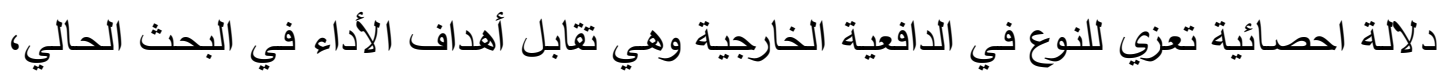

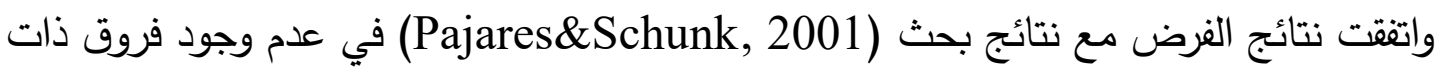

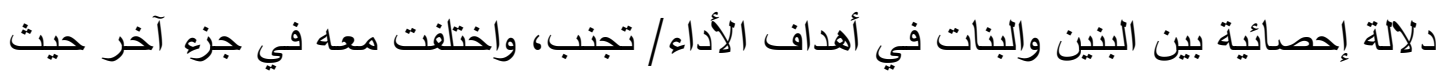

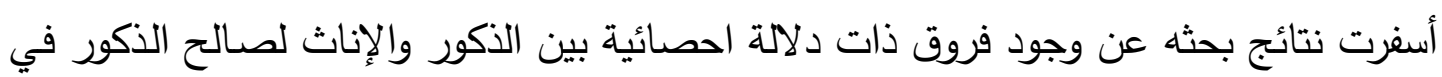

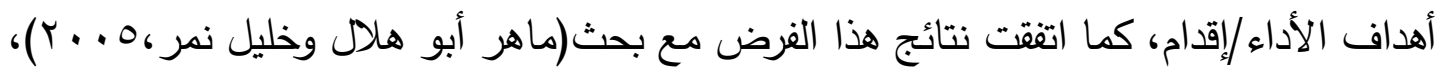

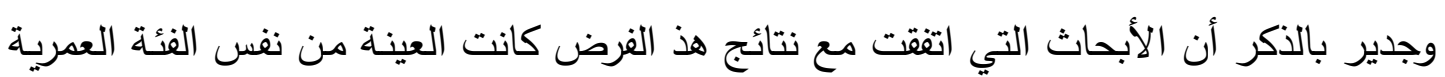

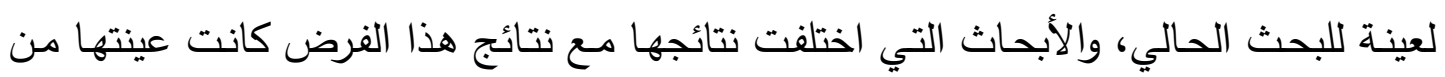
البالغين (طلاب الجامعة- - طلاب المرحلة الثانوية والإعدادية).

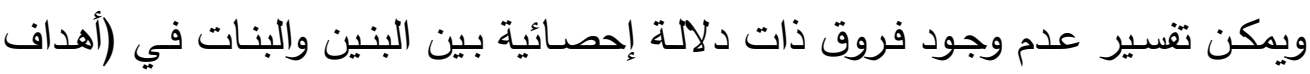

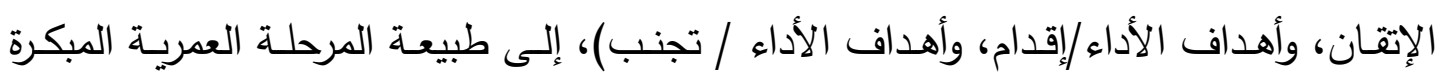
(الصف الخامس والسادس الابتدائي لم تتضح بعد الفروق بين البنين والبنات في أهداف الإتقان وأهداف الأداء. 


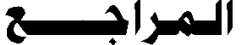

أحمد فلاح العلوان وخالد عبدالرحمن العطيان (• • ب). العلاقة بين الدافعية الداخلية الأكاديمية والتحصيل الأكاديمي لدى عينة من طلبة الصف العاشر الأساسي في مدينة معان. مجلة

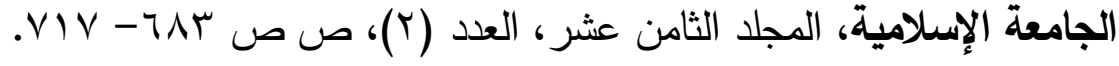

تاعوينات على (9 . . ب). التواصـل والتفاعل في الوسط لمدرسسي. الجزائر ، المعهد الوطني لتكوين مستخدمي التربية وتحسين مستواهم، وزارة التربية الوطنية.

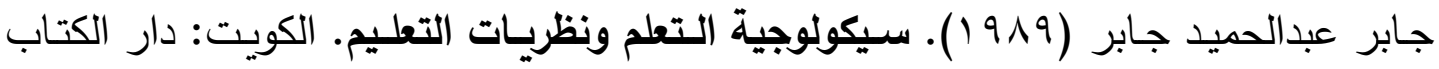
الحديث. جابر عبد الحميد جابر (ع . • ץ). نحو تعليم أفضل: إنجاز أكاديمي وتعلم

$$
\text { اجتماعي وذكاء وجداني. القاهرة: دار الفكر العربي. }
$$

جميل حمداوي (0 1 • ب). التواصل اللساني والسيميائي والتربوي. WWW.alukah.net.

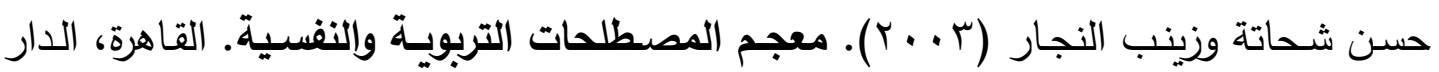
المصرية اللبنانية.

طه أحمد الزيدي( • ( • ( ). معجم مصطلحات الدعوة والإعلام الإسلامي. العراق: دار الفجر .

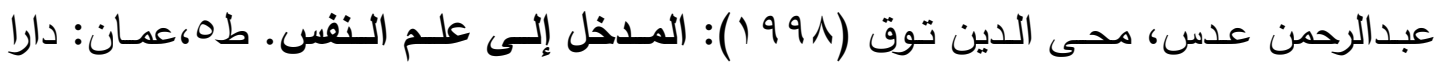
لفكرللطباعة والنشر والتوزيع - ماني عبدالمجيد نشواتى (1991). علم النفس التربوي. عمان: دارا لفرقان. على بن سليمان الثعيلى (V . . r). الدافعية الداخلية والخارجية وعلاقتها ببعض المتغيرات لدى طلبة الحلقة الثانية من التعليم الأساسي بسلطنة عمان، رسالة ماجستير غير منشورة، كلية التربية، جامعة الملك قابوس، سلطنة عمان. على راشد (r . . r). خصـائص المعلم العصـري وأدواره الإثـراف عليـه- تدريبه. القاهرة: دار الفكر العربي.

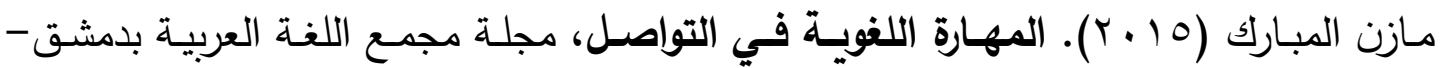

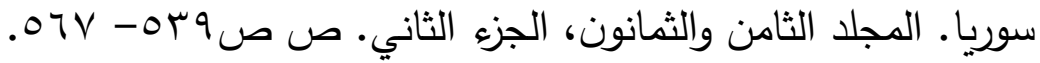
ماهر محمد أبو هلال، خليل نمر درويش (0 . . ץ). البناء العاملي لتوجهات الأهداف وعلاقتها بالتحصيل الدراسي لدى طلبة المدارس وطلبة الجامعـة: دراسـة للدافعية في إطار علم الـنفس الاجتمـاعي والشخصـية. دراســات العلـوم الإنســانية والاجتماعيـة. الجامعـة

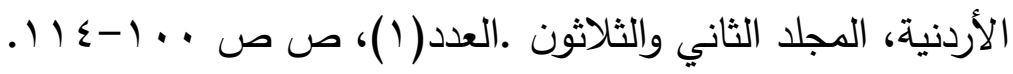


محمد السيد عبدالمعطى (997 19). مكونـات بيئة التعلم المدرسي وعلاقتها بالدافعيـة للدراسـة

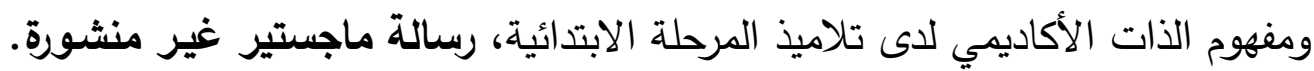

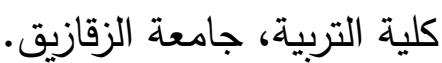

منال طلعت محمود (Y . . ب). مدخل إلى علم الاتصال. المعهد العالي للخدمة الاجتماعية. الإسكندرية.

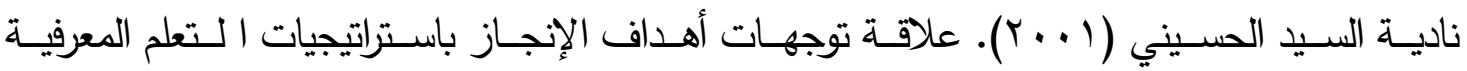
واستراتيجيات ما وراء المعرفة وقلق الاختبار لدى الطلاب المتفوقين دراسيا. دراسـات تربويـة

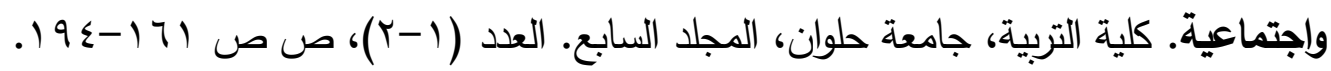

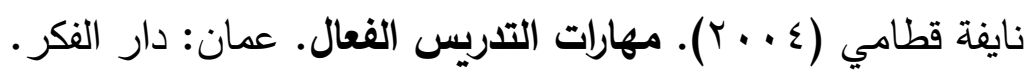

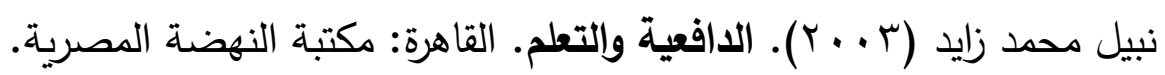

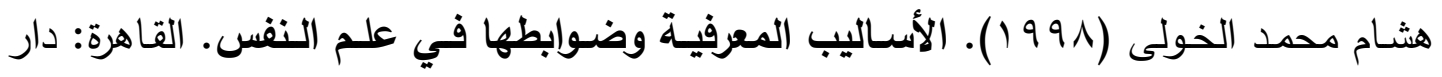

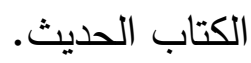

Ames, C (1992). Class, Structures and Student Motivation. Journal of Educational Psych Arias, J.F. (2002). Recnt Perspectives in the study of motivation: Goal Orientation Theory. Electronic Journal of Research in Educational Psychology, Vol.12, No (1) ,Pp35-62.ological, Vol.84, No (3), Pp261-271.

Arias, J.F. (2002). Recnt Perspectives in the study of motivation: Goal Orientation Theory. Electronic Journal of Research in Educational Psychology, Vol.12, No (1) ,Pp35-62.

Ayden, M. D; Miller, J. K; Xiaojun, Y., Mentes, T., Leblebici, D.N.,Yildiz, M., Erkul, E.(2013).Nonverbal Immediacy and Perception Across Curvey in Turkey, USA, and China, Hacettepe Universities Egitimm. Faculties Dergisi. H.U. Journal of Education, No(44),Pp27-42.

Broussard, S.C. (2002). The Relationship Between Classroom Motivation and Academic Achievement in First and Third Graders, Unpublished Master Thesis, Louisiana University.

Christophel, D.M. (1990). The Relationships among Teacher Immediacy Behaviors, Student Motivation, And Learning. Communication Education, Vol. 39, Pp322-340.

Dweck, C. S.(1986).Motivational Process Affecting Learning. American Psychologist, Vol.41, No(10),Pp1040-1048. 
Elliot, A., \&Church, M. (1997). A Hierarchical Model of Approach and Avoidance Achievement Motivation. Journal of Personality and Social Psychology, Vol.72, No (1), Pp218-232.

Elliot, A .J , Murayama, K., \&Pekrun, R. (2011).A3X2 Achievement Goal Model. Journl of Educational psychology .http:// researchgate. net/publication.9/6/2016.

Elliot, A.J \&McGregor, H.A; (2001). A2X2 Achievement Goal Frame work. Journal of Personality and Social Psychology. Vol.80, $\mathrm{NO}(3)$, Pp501-519.

Furlich, S.A\& Dwyer, J.F .(2007).Student Motivation and Instructor Immediacy in Community College Mathematics Classes. The Mathematics Educator, Vol. 10, No(2), Pp55-70.

Furlich, S.A.(2016). Understanding Instructor Nonverbal Immediacy, Verbal Immediacy, and Student Motivation at a Small Liberal Arts University. Journal of the Scholarship of Teaching and Learning, Vol.16, No (3), Pp11-22.

Gorham, J.(1988).The relationship Between Verbal Teacher Immediacy Behavior and Student Learning. Communication Education, Vol.37,No(1),Pp40-53.

Johan, V.L.(2012).Student and Teacher Perceptions of Teacher Immediacy Behaviors on Student Motivation to Learn Science.

Unpublished Doctoral, Gardner-Webb University.

Lane, D.(2009).Communication With Student to Enhance Learning.www.education.com.13/1/2016.

Mehrabian, A. (1971)Silent Messages. United States. Of America.

Mirzaei, F; Phang, F.A, Sulaiman, S, \&et al.(2012).Master Goals, Performance Goals, Student's Beliefs and Academic Success: Metacognation A mediator. Procedia -Social and Behavioral Sciences, No(46),Pp3603 - 3608 .

Mustafa, S.M; Roslan, H.E, \&Noah, S, M.(2011).Can Mastery and Performance Goals Predict Learning Flow Among Secondary School Students. International Journal of Humanities and Social Science, Vol.39, Pp93-98.

Nicholls, J.G.(1984). Achievement Motivation: Conceptions of Ability, Subjective Experience, Task Choice, and Performance, American

Psychological Association, Vol. 91, No(3),Pp328-346. 
Pintrich, p.(1999). The role of motivation in promoting and sustaining self-regulated learning. International Journal of Educational Research, Vol.31, Pp 459-470.

Pintrich,P: (2000). An Achievement Goal Theory Perspective on Issues in Motivation Terminology, Theory, and Research. Contemporary Educational Psychology, Vol.25, No (1),Pp92-104.

Radoevich, D. J; Allyn,M.R,\&Yun,S.(2007).Goal Orientation and Goal Setting: Predicting Performance by Integrating Four- Factor Goal Orientation Theory With Goal Setting Processes. Seoul Journal of Business, Vol.13, No(1)Pp21-44.

Rahmani;P.(2011).The Relationship between self-esteem, achievement goals and academic achievement among the primary school students.

Procedia Social Behavioral Sciences,No(29),Pp803-808.

Richmond, V.P; McCroskey, J.C;\&Johnson, A.D; (2003).Development of the Nonverbal Immediacy Scale (NIS): Measures of Self - and Other-Perceived Nonverbal Immediacy. Communication Quarterly, Vol.51,No(4),Pp504-517.

Soini, H.T; Aro, K.S; Niemivirta, m.(2008).Achievement Goal Orientations and Subjective Well-Being: Aperson- Centred, Analysis. Learning and Instruction, No(18),Pp251-266.

Somuncuoglu, Y; Yildirim, A:(1999).Relationship Between Achievement Goal Orientations and Use of Learning Strategies. The Journal of Educational Research,Vol. 92,No(5),Pp267-277.

Tüm, G.(2010).An Investigation on Teacher Nonverbal Immediacy in Turkish as Aforeign Lnguage. the Journal of Social Science Studies, Vol.3,No.1,Pp49-60

Vanden Bos, G. R:(2015). APA Dictionary of Psychology. Second Edition, American Psychologica.

Velez, J.J;\& Cano, J :(2012). Instructor Verbal and Nonverbal Immediacy and the Relationship With Student Self-efficacy and Task Value Motivation. Journal of Agricultural Education, Vol.53, No(2), Pp. 87-98. 